\title{
Crowding out the change: business networks and persisting economic elites in the South of Italy over Unification (1840-1880)
}

\author{
Maria Carmela Schisani ${ }^{1}$ - Luigi Balletta ${ }^{2} \cdot$ Giancarlo Ragozini $^{3}$
}

Received: 9 October 2018 / Accepted: 8 March 2020 / Published online: 16 March 2020

(C) The Author(s) 2020, corrected publication 2020

\begin{abstract}
In this article, we study the effect of the Unification on the network power of economic elites in the South of Italy. We study the persistence of economic elites as evidence of the stability of the institutional set up beyond the effect of Unification, and thus as a primary explaining factor of the persistence of social forces slowing and opposing modernization. We use original archival data on the universe of Naples enterprises to build the networks of business relations between individual economic actors for the 20-year period immediately before and after Unification. The persistence of network power and its determinants is tested via a difference-in-difference model. The main finding is that economic elites persist over Unification. The longterm business relations, rooted in the Bourbon period, the persisting lobbying power of the financial industry, the close collusive ties with potential foreign competitors and the closeness to politics after 1861 are all elements that explain how the Southern economic elites were able to crowd-out the change.
\end{abstract}

Keywords Economic elites · Social network analysis · Italian Unification · Economic history of the South of Italy in the nineteenth century

JEL Classification N23 $\cdot \mathrm{N} 83 \cdot \mathrm{N} 93 \cdot \mathrm{L} 14$

Maria Carmela Schisani

schisani@unina.it

1 Department of Economics and Statistics, Federico II University of Naples, Via Cintia, 26,

Naples, Italy

2 Department of Economics, Management and Institutions, Federico II University of Naples, Via Cintia, 26, Naples, Italy

3 Department of Political Sciences, Federico II University of Naples, Via Rodinò, 22, Naples, Italy 


\section{Introduction}

Southern backwardness is a crucial issue in the historical and economic literature on the process of Italian economic development. The Southern Question (Questione Meridionale)—first posed by a small group of intellectuals (i.e., meridionalisti) to the national ruling class in the mid-1870s (Franchetti and Sonnino 1877; Villari 1878; Fortunato 1911) — has been the object of a long-lasting controversial debate throughout the history of unitary Italy, and it is still matter of discussion (Pescosolido 2017).

More recently, a new strand of research in economic history, focused on a quantitative approach, has opened up a new terrain of debate on the long-term causes of the Italian divide. Moving away from the tradition of previous qualitative analyses, these studies have provided empirical evidence on the determinants of Italy's longterm regional development by producing estimates at the regional or provincial level of economic growth (GDP) (Daniele and Malanima 2011; Felice 2013; Ciccarelli and Fenoaltea 2013), various measures of industrial productivity and innovation (Toninelli and Pavese 2012; Basile and Ciccarelli 2018; Ciccarelli and Fachin 2017; Nuvolari and Vasta 2017), living standards and inequality (Felice and Vasta 2015; Vecchi 2017; Felice 2018) and other indices like market potential (Missiaia 2019).

Generally, these studies have made significant advances in dating the origins of the north-south divide and in explaining its causes. However, many controversies remain as long-run trends in regional indicators are difficult to estimate due to the lack of systematic quantitative evidence from before Unification.

A number of studies find that the economic performance of the south was roughly at par with the north at Unification (Daniele and Malanima 2011; Ciccarelli and Fenoaltea 2013) with a definite gap opening up only after the 1870s (and much more from 1891 to 1911) and later in the first decades of the twentieth century (Iuzzolino et al. 2013). Conversely, more recent works on the reconstruction of relative levels of GDP suggest that an economic gap already existed at Unification (Felice 2012, 2018; Felice and Vecchi 2015). This interpretation is also supported by the analysis of international trade trends (Federico and Tena-Junguito 2014), as well as by estimates of real wages (Federico et al. 2019).

Even the literature that discusses the causes of the divide, going beyond the similarity of regional income levels, seems more inclined to agree with the conventional wisdom that considers disparities as preexisting Unification (Cafagna 1989).

For instance, the strand of literature that stresses geographical factors as determinants of economic development recognizes a "natural" advantage for the north when compared to the south both in terms of resource endowment (water) (A'Hearn and Venables 2013) and better access to the national market (Missiaia 2016; Daniele et al. 2018) as "original" drivers of different regional paths of industrialization.

Also the focus on social, cultural and institutional factors hints at a gap possibly centuries old. A traditional view, based on more abstract concepts, emphasizes the role of deep-seated cultural factors, peculiar social structures, institutional context, trust and lack in social capital in explaining south backwardness (Banfield 1958; Putnam 1993). The more recent quantitative works renew this view introducing 
more concrete measures of human and social capital, considered as crucial for economic growth. In this strand of interpretation, the north results persistently ahead of the south in various social indicators like social capital (Felice 2018), access order (Di Martino et al. 2019), life expectancy, height, nutrition (Vecchi 2017), a composite human development index (HDI) (Felice and Vasta 2015) and above all in terms of literacy rates, for which the south largely lagged behind from before Unification (Ciccarelli and Weisdorf 2019).

In some works, culture complements the institutional focus for its role in shaping institutions and thus in explaining their different functioning between regional areas (A'Hearn 2000, 2005). Other studies, conversely, tend to consider socio-institutional factors as a separate issue (Felice 2013, 2018) explicitly dating back the gap before 1861. In the institutional explanation, a key role is played by southern elites (Nitti 1900; Gramsci 1935), a topic newly at the forefront of the debate. The existence of a narrow privileged elite in the south, inferred from measures of personal inequality in different Italian areas, has been recently suggested as a revealing trait of a preexisting regional gap in 1861 (Felice 2018). Elites are described as producing and supporting "extractive" political and economic institutions (Acemoglu and Robinson 2012), this way hampering modernization (e.g., the failure of political revolutions) (Felice 2013) and/or pursuing "passive modernization" to their own advantage (Felice and Vasta 2015). Importantly, this analysis stresses the persistence of these local elites over Unification, also favored by the policies of the new liberal governments conceived to maintain upper classes privileges (Felice 2018). Thus, Unification seems not to fill the institutional gap between the north and south but rather perpetuate it.

The present article aims to give an original contribution to the revived interest in the institutional explanation of southern backwardness. We study the persistence of economic elites as evidence of the stability of the institutional set up beyond the effect of Unification, and thus as a primary explaining factor of the persistence of social forces slowing and opposing modernization.

The issue has been already addressed in the socio-historical literature on the south of Italy, in which claims about the formation of a local entrenched elite have been largely speculative and backed up with qualitative evidence. Scant information provides a fragmented picture on the local business and financial environment and hints at the persisting presence of a local business oligarchy for pre-Unification (Davis 1979). The topic remains rather blurred, and a systematic and structured work on the evolution of southern elites over the Unification is still lacking. This gap leaves an important space for research. Unification really marked a great reversal in economic policies for the south of Italy, with the transition from the closed system of the protectionist Bourbon monarchy to the trade and capital openness of the Italian liberal governments. What these deep changes produced in terms of balance of power within the local business and financial elite is still fairly unknown. We try to fill this gap.

We address the topic by empirically investigating the business elite of Naples, the largest city and the most representative to interpret the dynamics of power that affected the economy of the continental south in the nineteenth century. 
Backed by newly built large relational data on the universe of Naples enterprises in the entire century, we first reconstruct the network of individuals that participate in its business life. In our analysis, a link between two actors is formed when both participate, in various forms, to the same firm. On these networks, we apply quantitative tools from social network analysis (Wasserman and Faust 1994; Best and Higley 2017) to characterize individual power and rigorously define a local elite.

Our main interest is studying the effects of the institutional breakpoint of Unification (1861) on the elite and, more generally, on the determinants of network power. We have in mind two possible outcomes. On the one hand, Unification could result in a disruption of the power of incumbents thanks to a more competitive environment fostered by the subsequent liberalization of trade (1861) and capital flows (1865) (Rajan and Zingales 2003). On the other hand, network relationships induce path dependencies (Scott 1997; Carroll and Fennema 2002) and, as a result, elites might survive even in the presence of strong external shocks (Acemoglu and Robinson 2008).

We use a difference-in-difference (DID) estimation approach, focusing on the 20-year period before and after Italian Unification, and interpreting the institutional breakpoint as a natural experiment. More specifically, we test the effects of Unification on: (1) the persistence of network power of the elite group; (2) the ranking of economic sectors in terms of network power; (3) the difference in network power of local and foreign actors. Finally, for the post-Unification, we also test for the relationship between business network power and participation in politics.

Our results point to continuity rather than disruption in the power of elites. An index of individual network power indicates that the narrow group forming the elite did not lose power over Unification. Network power was mainly associated with participation in financial firms, both before and after Unification. Elites maintained power by establishing strong relationships with powerful foreign actors and by participating in local and national political bodies of the newly formed Kingdom of Italy, revealing the merging of economic and political interests typical of ruling elites.

The paper proceeds as follows. Section 2 briefly outlines the historical framework. Section 3 describes the dataset used in our study and the methodology. Section 4 presents the results. Section 5 contains a discussion of the results and some concluding remarks.

\section{Historical framework}

To situate our research, it is helpful to review some of the key points that explain the interest in studying Naples, in itself and as the economic center of the continental South.

The historical literature is unanimous in considering Naples the political, economic and financial core center of the mainland south at least until the end of the nineteenth century (Galasso 2009). According to the classical eighteenth century illuminist topos, it was the "monstrous swollen head on a shrunken body" (Palmieri 
1788 , p. 210), the "big city that devours the kingdom [...] where all the money percolate[d] from Provinces without returning back" (Genovesi 1775, II, p. 177).

As the largest southern consumer market, it attracted most of interprovincial and international trade flows of goods and services. The most of southern Italy's import and export trade passed through its port, the largest one on the Tyrrhenian coast south of Leghorn (Macry and Villani 1990; Conti and Schisani 2011).

Educated and cultural elites as well as aristocrats and rentiers from different southern provinces, bureaucrats, merchants, financiers and bankers concentrated their business in Naples (Aliberti 1974; Massafra 1988; Macry 1974, 1990). The strongest vested-interest groups had always been concentrated and city-based since Naples provided the best networking opportunities, also thanks to the presence of many formal political, economic and financial institutions (Frascani 1990).

The big city was the place of the decision making, in which functional or dysfunctional social and economic dynamics took shape having an influence on everywhere in the south. For the pre-Unification period, the literature describes the formation of a city-based "financial oligarchy" and the long-lasting presence in Naples of the Rothschild bank (1821-1863) as having played a role in shaping the dysfunctional financial and economic system of the south. The narrow community of merchant bankers, grown in the closed and financially weak Bourbon system, is claimed as the major determinant of poor receptivity of the south to economic innovations (Demarco 1960; Davis 1979; Caglioti 2003, 2008; Schisani 2001, 2010). The monopolistic action of the Naples Rothschild house (1821-1863) in shielding the city financial structure from foreign competition has been assumed as a further element to explain the lack of financial innovation in the South (Gille 1967; Cuciniello 1976; De Matteo 2013; Schisani 2015).

For the period after Unification, when Naples lost its role of capital city, the literature tends to lose track of this specific pre-unitarian "financial oligarchy." So far, no studies exist that estimate the effects that Unification had on local interest groups right after the opening of the market, the removal of the Rothschilds' financial monopoly (1863) and the massive arrival of foreign capital to the south for the realization of broad-ranging infrastructural plans (i.e., railways, urban planning, public utilities such as lighting, water supply and distribution, and urban transport) (Gille 1968; Dumoulin 1990; Schisani and Caiazzo 2016). The debate on the southern Question rather focuses on the persistence of traditional ruling minorities such as landowners, aristocrats and notables ${ }^{1}$ and on their ability to climb the national political bodies by forming interest groups aiming to preserve power (Franchetti and Sonnino 1877). Except for few works (Aliberti 1979; De Benedetti 1990; De Matteo 2008), no comprehensive study on the Naples' business and financial structure exists, and we are left to wonder whether this specific city-based elite component was exclusively a matter of the Bourbon period.

\footnotetext{
1 These characters have been also described in popular novels, the most representative of which is Tomasi di Lampedusa's Il Gattopardo, as archetypes of the persistence of old privileges in the face of a changing society. In the words of the aristocrat Prince of Salina's nephew from the novel, "things must change if they are to remain the same".
} 


\section{Data sources and methods}

The key step for this study has been making the Naples and southern Italy nineteenth century business history queryable by building original data from previously unexploited archival sources, for a century where economic statistics and printed statistics on Naples and the south are scarce and sparse. Such an endeavor is important because, until now, targeted long-term datasets for extracting trends over long time periods on the south's entrepreneurial system are still lacking. ${ }^{2}$ Our work is indeed based on a unique and original database, IFESMez ${ }^{3}$ storing data on the universe of enterprises and companies operating in southern Italy between 1800 and 1913.

\subsection{The IFESMez database}

IFESMez has been tailored to meet the specific needs of a wider and long-term research project based on a transnational approach for studying southern Italy economic system. Data have been essentially collected through archival research. The primary source is the Mercantile Court archival funds (from 1883 on, Civil Court) available at the Naples State Archive. It has allowed us to collect data from official documents (including memoranda of association, balance sheets, appointments of directors, minutes of general meetings, etc.) provided to the courts by firms of any legal type. Note that the universe of firms includes firms legally registered in Naples and firms that are registered elsewhere but operate in Naples, or firms that are linked to actors and firms in Naples through actors which are co-shareholders/directors/ managers. On this base, data have been integrated with information deriving from other archival sources, gray literature, publications (journals, books, etc.), electronic sources, genealogies, etc. Since southern Italy business activities extended beyond boundaries that varied over time, the data gathering process has required the spatialization of archival and printed sources. Overall, the data have been gathered from Italian, French and Swiss archives and libraries (State Archives and Notary Archives of Naples, Italian State Archive in Rome, CARAN, CAEF and Municipal Archive of Paris, CAMT in Roubaix and National Libraries of Naples, Paris and Geneva).

At present, the database contains information regarding 3500 firms - created and/ or operating in Naples and its province-and almost 27,000 people for the period between 1800 and 1913. Whenever present, information on firms includes the start/end date of its life, the main objective of the firm as stated in its founding act, legal form (partnership, limited liability, join-stock, etc.), legal address, the number of offices, financial information regarding its starting capital and yearly balance

\footnotetext{
2 At present, very few works provide some regional data, from secondary sources, on pre-Unification since the 1820s, like the work by Federico and Tena-Junguito (2014) that investigates international trade trends for some pre-unitarian states and the work by Ciccarelli and Weisdorf (2019) that reconstructs literacy rates.

3 Acronym for Imprese, Finanza, Economia e Società nel Mezzogiorno-Enterprises, Finance, Economy and Society in the Mezzogiorno. It has been conceived and it is managed by Maria Carmela Schisani and Francesca Caiazzo and it is hosted on the web server of the University of Naples "Federico II"-www. ifesmez.unina.it.
} 
sheets, and the names of individuals or other firms related to the firm at different levels, including owners/partners, managers, auditors, etc. Information on individuals includes sex, date of birth, legal address and the names of other individuals and firms that are related to the individual again for different reasons. The construction of the database has been specifically conceived to reconstruct network ties within and between organizations in order to define size, composition and centrality of business groups and their mutations over time. Its relational structure links:

- Actors to firms through relations based on actors' roles within firms, such as partner, shareholder, director, auditor (member of the Collegio dei Sindaci), banker, notary, high-level technician (e.g., director general);

- Actors to actors through relations based on kinship and personal ties;

- Firms to firms through all forms of documented relations (cross-shareholdings, mergers and acquisitions, financial and trade relations, etc.).

These data represent, to our knowledge, the first dataset on the Naples business structure during the nineteenth century. It offers wide possibilities both for exploring and explaining the patterns of ties, considering their origins (e.g., dependent on legal constraints or on kinship ties, strategically or freely established), their effects, their changes in response to exogenous shocks (like the change of a political regime) and their consequences.

\subsection{Data construction}

For this paper from the IFESMez database, we have extracted, for the period 1840-1879, a dataset linking actors to firms through the role played by the actor within the firm. We choose the most extensive concept of role including shareholders, directors and managing roles. This results for the whole period in 8115 links between 1335 firms and 5576 actors.

The resulting affiliation network has been sliced by 20 -year period, producing two two-mode networks for the years 1840-1859 and 1860-1879 with the Italian Unification as cutting point. Note that in our dataset, the date of the link appears either as a start/end date or as a point date marking a year when the relationship was for sure in place. The attribution of the link, in each 20-year span, has been done by considering the start/end date whenever present and otherwise using the point date as existing within the 20 -year span. The value associated to each link represents how many times and how many different roles an economic actor played in a given firm.

In the present paper, we do not analyze the two-mode networks directly but, being interested in the relationships among economic actors, we have derived two temporal one-mode actors-by-actors networks following the usual projection approach (Everett and Borgatti 2013). For the purpose of characterizing interest groups and analyzing the determinants of power and centrality within the network, we have also created nodes attributes on the actors' nationality, the economic sector in which the firms they are linked to operate and their post-Unification political role. The data for nationality and the economic sector are contained in the IFESMez database, while 

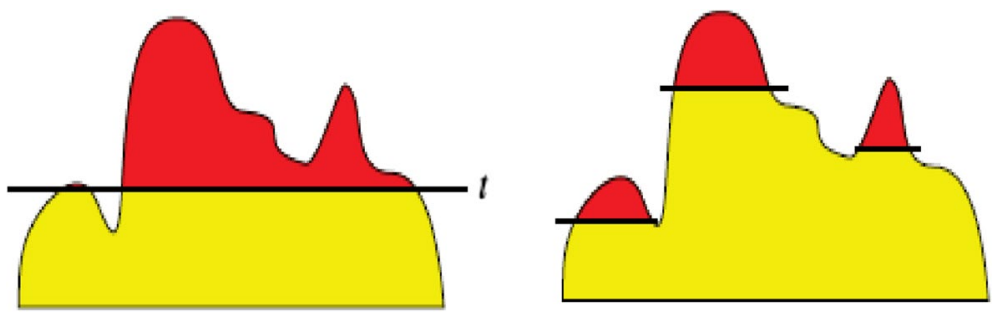

Fig. 1 Visualization of the Island concept Source: Batagelj et al. (2014); p. 55

for the political role, we have created a separate database from the official name lists of the members of the City Council of Naples, and the Parliament and Government of the Kingdom of Italy. The construction of these dummies is explained below.

\subsection{Methods}

In order to answer our research questions, we have selected a set of proper methods in the wide literature of network analysis. In particular, we look for methods suited to treat large networks and able to extract the relevant information in such networks, corresponding to the actors and firms playing an important role in the financial and economic network.

The analytic strategy consists in three main steps. Before starting our analytic strategy, we explore the network structure. We look at descriptive network characteristics and we visualize the networks using the Fruchterman-Reingold spring embedding algorithm, considering also nodes attributes that are relevant for the subsequent analysis. In this exploration, we compare network measures and their graphical representation for the two time periods before and after Unification.

\subsubsection{Step 1: looking for elites}

Starting from the concept of interest groups and elites, we have looked for those groups of actors that are strongly connected and central in the actor-by-actor networks. To pursue this aim, we have used the Island algorithm (Batagelj 2009). The algorithm is designed to find the important parts in large networks with respect to a given property of nodes or links, and to extract coherent well-connected part of networks for further study. By representing the computed property of nodes/links as a height of nodes/link and by immersing the network into water up to selected level (Fig. 1), the islands are derived (Batagelj et al. 2014). Given a threshold value t, it is possible to obtain a cut of the network and, by varying this level $t$, different islands are identified. Like in hierarchical clustering, different cuts are nested and determine a hierarchy. For our purposes, we have used the line island approach, which looks for a connected subnetwork with several nodes in a specified interval, such that the links inside the island have a higher weight than the links connecting nodes in the island with their neighbors, i.e., we look for actors that are mostly connected in terms of their joint presence into firms. This algorithm has been used in many cases similar 
to the one at hand (collaboration networks, co-authorship networks, co-decision networks in which actor are linked by their joint participation to team project, papers or group decisions). Furthermore, we have used the version of the algorithm that allow for multiple peaks, like on the right side of Fig. 1.

Given the results of the Island algorithm, we have first removed all the actors with a height equal to zero (the largest part in the two time spans), extracting the islands, consisting of actors with positive height. This process produces a set of islands that could be either connected or not. In some case, we have found isolated islands of actors that mainly correspond to large family-based firms or to small local system of firms integrating, for example, an insurance company, a small local bank and a set of firms in a specific productive sector (e.g., this is the case of pasta-makers, "pastai," located in the province of Naples). On the other hand, we have found also a set of islands that are connected to each other starting from the most central and dominant. Inside these central and dominant parts of the networks, we look for the elite by considering those actors with betweenness greater than zero, so that we define as members of the elites the actors with both positive island height and positive betweenness.

\subsubsection{Step 2: constructing actors' attributes and analyzing elite composition}

In order to analyze the composition of elite, we have compared the incidence of actor attributes in the elite to the incidence in the general population. In particular, we have considered the economic sectors of interest and the nationality of actors. We define nationality with respect to the Kingdom of Italy, thus an actor is foreign whenever national of a country different from post-Unification Italy. For the economic sector of interest, we refer to the modern official classification of economic activities (ATECO codes 2007 based on NACE revision 2) from ISTAT, and we have attributed firms to sectors on the basis of the main objective of the firm as stated in its founding act. Of course, the correspondence is rough, in the sense that we backed up the possible modern sector of activity from the (already rough) description of the firm's activity in the founding act. As sectors, we have considered finance, public utilities and transports, manufacturing and trade. ${ }^{4}$ Within the finance sector, we distinguish between insurance and banking. Also, within the trade sector, we distinguish between firms that operate in international trade and firms that

\footnotetext{
${ }^{4}$ As noted in the text, the sectors roughly correspond to the modern official classification of economic activities (ATECO codes 2007 based on NACE revision 2) from ISTAT:

- Finance: insurances, financial advisors, financial agents and brokers, commodity contracts dealers, financial representatives, portfolio management, real estate finance, banks (ATECO codes K);

- Public utilities and transports: gas, electricity and water suppliers, railways, tramways, navigation, telecommunications and other minor services (ATECO codes D, E, H);

- Manufacturing/Industry: craftworks, manufacturing, heavy and light industry, mines, transport constructions, building constructions (ATECO codes B, C, F);

- Trade: retail and wholesale firms for domestic and foreign goods trading, trade agencies (ATECO code G).
} 
Table 1 Number of firms by sector of activity

\begin{tabular}{lll}
\hline & PRE & POST \\
\hline Finance & Banking: $79(16.70 \%)$ & Banking: $144(14.66)$ \\
& Insurance: $25(5.28 \%)$ & $\begin{array}{c}\text { Insurance: } 50(5.09 \%) \\
\text { Other financial services: } \\
\text { Other financial ser- } \\
\text { vices: } 32(3.26 \%)\end{array}$ \\
& $\begin{array}{l}\text { Total finance: } 109 \\
\text { Total: } 226(23.01 \%)\end{array}$ \\
& $(23.04 \%)$ & \\
Public utilities & $44(9.30 \%)$ & $50(5.09 \%)$ \\
and transports & & \\
Manufacturing & $92(19.45 \%)$ & $164(16.70 \%)$ \\
Trade & International trade: 33 & $\begin{array}{c}\text { International trade: } \\
111(11.30 \%)\end{array}$ \\
& $(6.98 \%)$ & Trade (not Inter- \\
& Trade (not Interna- & national): 360 \\
& tional): $160(33.83 \%)$ & $(36.66 \%)$ \\
& Total trade: 193 & Total trade: 471 \\
& $(40.80 \%)$ & $(47.96 \%)$ \\
& & 982 \\
\hline Total & 473 &
\end{tabular}

In each cell, the number of firms in each sector (in parenthesis the percentage of the period total). In each period, the sum of the number of firms in each sector does not add up to the total number of firms because some firms do not belong to any of the sectors we classified, and because we attributed some firms to more than one sector whenever it was not possible to determine from the founding act which of the declared activities was the primary activity of the firm

do not. ${ }^{5}$ Note that on the basis of the description of the firm's main objective in its founding act, one firm might operate in more than one sector. The number of firms by sector of activity is summarized in Table 1 .

We have then created actor sector dummies that indicate if an actor is linked to at least one firm in that sector. In addition, we have created a diversification dummy that indicates whether that actor is linked to a firm that operates in more than one sector or to multiple firms that operate in different sectors. For the political role, we created a separate database with the list of all Naples City Council members from 1861 to 1899 , and all members of the Parliament and Government from 1848 to 1899 (from 1848 to 1860 Parliament and Government are the ones of the Regno di Sardegna). Using this, we have cross-checked by first and last name whether each actor in our database belonged to one of these bodies in the post-Unification period (until 1879), creating dummies classifying it accordingly as a local politician (City Council) or a national politician (member of the Parliament or of the Government) if at least once he or she has been part of these bodies. In the analysis, we use a single

\footnotetext{
5 The attribution of International to a Trade firm has been done by running a search in the objective of each Trade firm, as stated in its founding act, for words that are related to import, export or that reference to foreign countries. Whenever the search yields a positive, that firm is considered an International Trade firm. Thus, a firm is not in International Trade whenever there is no reference in the founding act to those words.
} 
politician dummy that indicates whether the actor is a politician, either at the local or national level or both.

\subsubsection{Step 3: estimating the effect of Unification via a difference-in-difference model}

As a last step of the analysis, we have estimated the effect of the Unification on the determinants of network power with a DID model. We have computed for each actor a centrality measure based on degree, defined as

$$
\text { Power Index }=\log \left(1+\text { Degree }_{o m} \times \text { Degree }_{t m}\right)
$$

where Degree $_{o m}$ is the degree in the one-mode network (i.e., the number of other actors to whom an actor is connected) and Degree ${ }_{t m}$ is the degree in the two-mode network (i.e., the number of firms to which an actor is linked). Our working assumption is that the more connections an actor has, the more power it can exert inside the network, due for example to being able to intercept a larger flow of information, or to enter a larger number of favor exchanging relationships. ${ }^{6}$ We therefore call it a power index. We have combined the two degrees as both are relevant to characterize the extent of connectedness of an actor in the network. Consider two actors A, $\mathrm{B}$ with the same degree in the one-mode network (other actors to whom he is connected) but $\mathrm{A}$ is in one firm and $\mathrm{B}$ in two firms. Arguably, the connective ability of $\mathrm{B}$, and thus his network power, is more than that of $\mathrm{A}$. One reason could be that without A other actors in the single firm would still be connected, while without B actors in the two different firms might not even have a path linking them. By taking the product of the two degrees, we account for this effect since the weight on a connection in the one-mode network increases with the number of firms an actor is linked to. We take the logarithm because the distribution of the two measures is highly skewed, and we add one to avoid taking the log of zero.

We have computed this variable, and the dummies for elite, sector, nationality and politics for all actors present in the database. This generates an unbalanced panel with two time periods, with, respectively, 1796 and 4400 observations. We then estimate the effects of Unification by using pooled OLS estimators.

\section{Results}

\subsection{The evolution of the Naples business network: network measures}

Table 2 displays the network measures of both the two-mode networks actors-byfirms and its projection over actors for the two decades before and after the Unification. Over Unification, comparing the 20-year period before and after, there is a

\footnotetext{
6 The degree can be also related theoretically to the power of coalitions of nodes in cooperative games on networks (see Van Den Brink et al. 2008).
} 
Table 2 Descriptive measures for temporal two-mode and one-mode networks

\begin{tabular}{lll}
\hline & Pre-unification & Post-unification \\
\hline \# Of actors & 1796 & 4400 \\
\# Of actors with degree equal to 1 & $1186(66 \%)$ & $3079(70 \%)$ \\
\# Of firms & 473 & 982 \\
\# Of firms with degree less than 2 & $239(50 \%)$ & $491(50 \%)$ \\
Two-mode network (actors-by-firms) & & \\
\# Of links & 2942 & 6952 \\
Actor average degree & 1.63 & 1.58 \\
Firm average degree & 6.21 & 7.1 \\
One-mode network (actors-by-actors) & & 82,802 \\
\# Of links value =1 & 28,456 & 37,715 \\
\# Of links value $>1$ & 8615 & 54.780 \\
Average degree & 41.282 & 0.5803 \\
Gini index (degree) & 0.6235 & 463 \\
\# Of components & 172 & $2789(63.39 \%)$ \\
Size of the largest component & $1221(67.98 \%)$ & 0.029 \\
Network betweenness centralization & 0.096 & 0.030 \\
Max value betweenness & 0.097 & $3676(83.5 \%)$ \\
\# Actors with 0 betweenness & $1418(78.9 \%)$ & 0.9684 \\
Gini index (betweenness) & 0.9570 & $27(565$ actors $)$ \\
\# Of islands & $30(276$ actors) \\
\hline & & \\
& & \\
& &
\end{tabular}

significant increase in the number of actors involved in the business community in Naples (approximately by a factor of 2.5) and firms (by a factor of 2). The percentage of actors with degree equal to 1 and of firms with degree less than 2 is almost stable over the two periods. This means that even in the expanded business community related to the new institutional phase, the largest part of the business structure remains characterized by small individual firms and family-based general partnerships. This is also confirmed by the average actor and firm degree that remain quite stable. Looking at one-mode networks, the distribution of actors' centrality measures is unequal in both periods. The Gini index computed on the degree distribution (Hu and Wang 2008) is in both cases close to 0.6, while for the betweenness, it is almost equal to the maximum value. The very large value of the Gini index for the betweenness is explained by the fact that a large number of actors have 0 betweenness. This implies that a few number of actors are able to play as brokers of the network connecting interest groups within the business environment. The presence of quite strong inequality in the distributions of both measures of centrality suggests the existence of elites in both periods.

Figure 2 presents graphical visualizations of the pre- and post-unification networks. Although the number of actors increases from pre to post, it is evident that the structure of the network remains quite similar. Even though visually different, indeed, the two structures are both formed by many nodes that are isolated or belonging to small components (located on the boundary of the layout thanks to the 

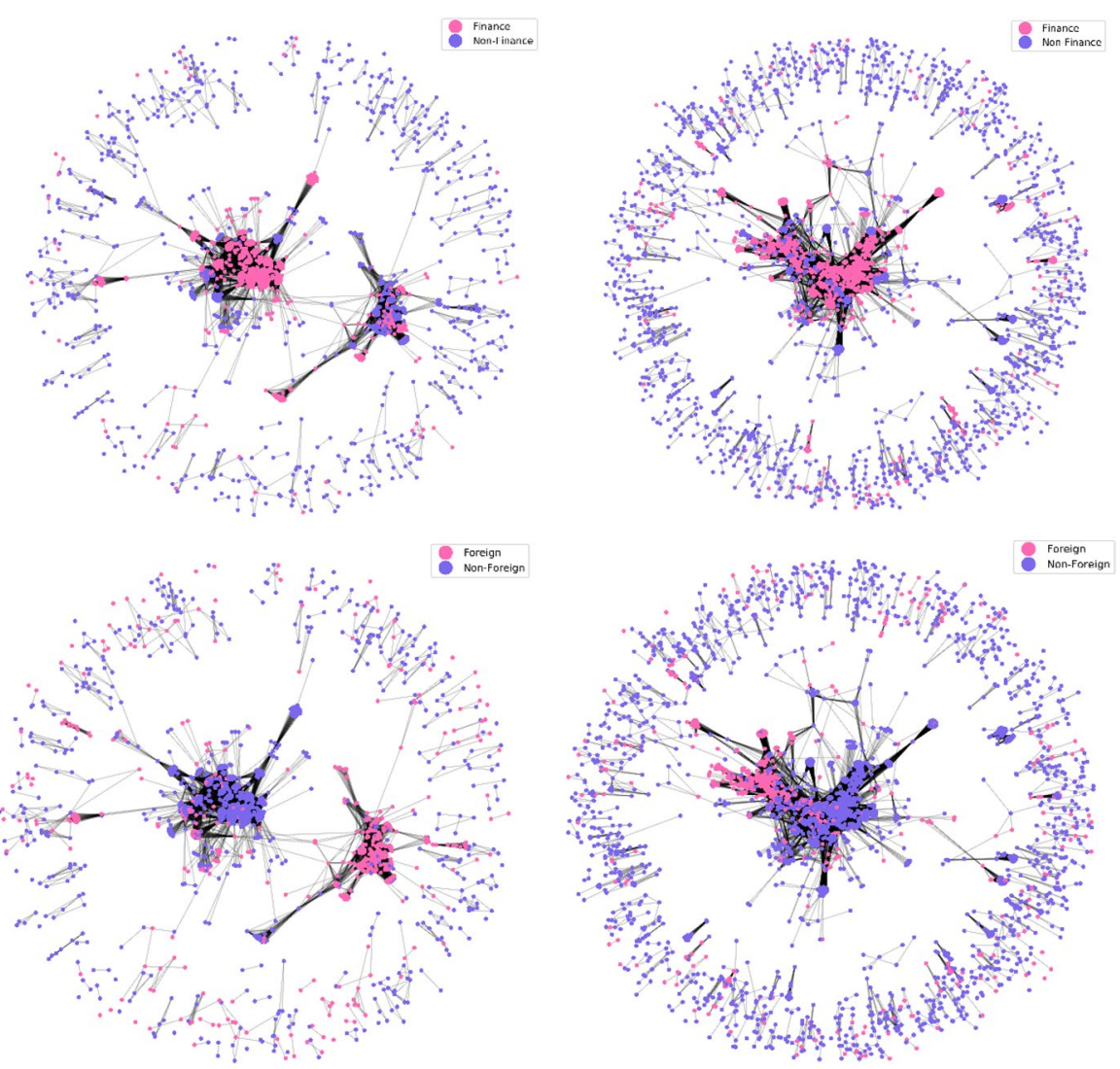

Fig. 2 Naples business networks: pre-unification (left panels), post-unification (right panels)

features of the Fruchterman-Reingold algorithm), and by a largest connected component (at the center of the layout). The difference between the two is rather due to the composition of the largest connected component in the first graph. The Fruchterman-Reingold algorithm tends to highlight two communities in pre-Unification that represent the distance between the foreign financial and entrepreneurial interests in Naples and the local ones that in post-Unification merged (see the description below for the Banca Fruttuaria and the Società per la rete di ferrovie da Napoli al Mare Adriatico). Note that the percentage of actor in the largest connected component also remains stable. In the figure, we also color nodes on the basis of attributes which will be central to our analysis. The upper panels contrast actors that are connected to firms in finance vs actors that are not. It is evident that actors in the largest connected component are for the vast majority involved in finance, and individuals involved in finance indeed mostly belong to the largest connected component. The lower panels contrast foreign and non-foreign actors. We note the presence of many foreign actors in the isolated or small components part of the network and that the largest connected component is formed in majority by non-foreign actors. However, 

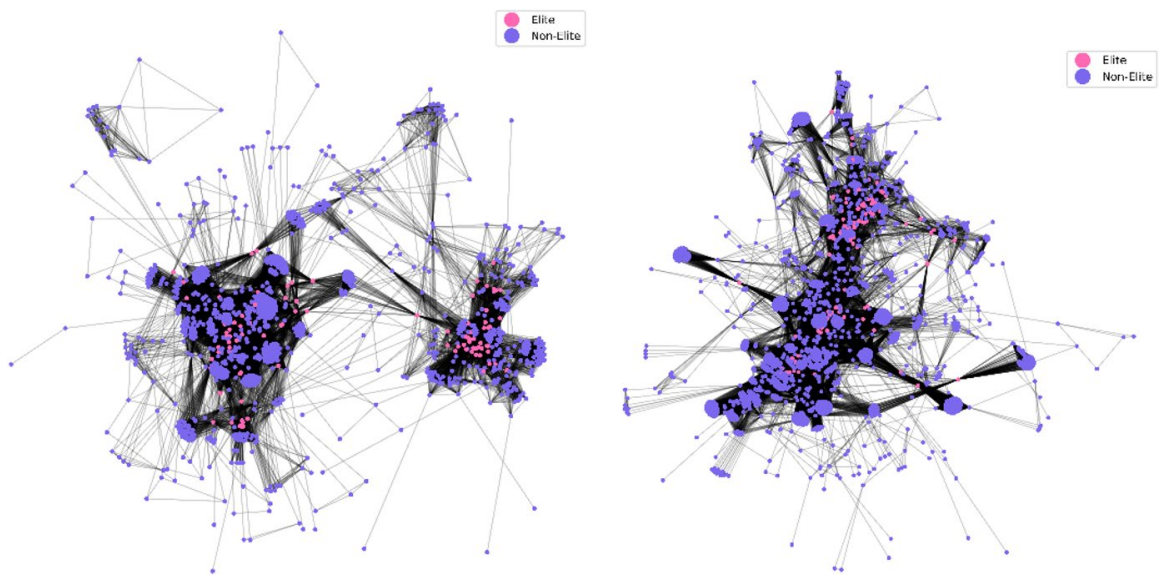

Fig. 3 Naples business networks (largest connected component): pre-unification (left panel), post-unification (right panel)

it is not true that foreign actors are completely absent from the core of the network, but rather it seems that they are linked to it but they tend to cluster together forming many connections among themselves and few connections with local actors. These attributes will be at the center of our quantitative analysis in the following sections.

\subsection{The composition of the elite}

Our algorithm selected an elite formed by 93 (5.18\% of the sample) and 104 individuals $(2.36 \%$ of the sample) for the pre- and post-unification networks, respectively. Figure 3 shows the position of elite actors within the largest connected components of the networks. It is evident that the algorithm selects individuals who hold a central position as they sit on many paths that join a multitude of actors and lay within the most densely connected parts of the network.

\subsubsection{Origins and persistence}

In Table 8 in the Appendix, we report the full list of actors in the elite, ranked in terms of power index. These are big linkers, generally tied to at least 4 firms. The list captures a well-focused picture of what until now has been the rather evasive concept of a southern business elite. It reveals four main characterizations across the two periods in the composition of actors: (1) primary merchant bankers of Neapolitan origins (e.g., Pietro Volpicelli, Mariano Arlotta, Leopoldo Persico, Tito and Teodorico Cacace) or Naples-based but coming from other regions of the south (e.g., Luigi Bonaventura Balsamo from Apulia, Giovanni Vittorio Englen from Calabria) and from foreign countries (e.g., Ilario Degas, Oskar Meuricoffre, Giovanni Auverny, Edouard Cahen d'Anvers); (2) landowners and members of the aristocracy (e.g., Gaetano e Giovan Battista Serra Principi di Gerace, Ferdinando Lucchesi Palli, Girolamo Giusso Duca del Galdo, Carlo Lefebvre Conte di Balsorano); (3) fairly 
Table 3 Persistence of the elite over unification

\begin{tabular}{lll}
\hline & $\begin{array}{l}\text { Elite (POST) } \\
(1)\end{array}$ & $\begin{array}{l}\text { Elite (POST) } \\
(2)\end{array}$ \\
\hline Elite (PRE) & $\begin{array}{l}0.638^{* * *} \\
(0.223)\end{array}$ & $\begin{array}{l}0.650 * * * \\
(0.240)\end{array}$ \\
Observations & 4400 & 620 \\
Pseudo R-squared & 0.365 & 0.350 \\
\hline
\end{tabular}

Standard error in parenthesis. *** $p<0.01$, ** $p<0.05, * p<0.10$. Probit (1) is run on the full post-unification sample $(n=4400),(2)$ is run on the subsample of actors $(n=620)$ which are present before and after unification. The regressions include controls for sectors (Banking, Insurance, Trade and Manufacturing), diversification of economic activity and participation in politics

unknown businessmen coming from different social ranks (e.g., Pietro Palomba, Domenico Gallotti); (4) communities of primary foreign bankers and entrepreneurs (e.g., Isaac and Emile Pereire, Basile Parent, Charles Mallet, Edouard Blount, Isaac E. Hentsch), members of that transnational corporate elite who, moving from the European financial core centers, were exporting capital and technological know-how (mainly related to transport and public utilities) to the peripheries.

In the list of names, we note a fair number of actors which are present in the elite before and after Unification. Does participation in the elite in the pre-Unification affect the likelihood of being in the elite after? In Table 3, we run a simple probit on the post-Unification full sample (column 1) and on the post-unification subsample of actors present in the database before and after (column 2), where the dependent variable is the post-Unification dummy and the explanatory variable is the dummy pre-Unification, controlling for sectors and participation in politics. The coefficient is positive and statistically significant, showing that being in the pre-Unification elite increases the likelihood of being in the elite also post. This is a first indication of a certain persistence of power across Unification.

Moreover, additional information from the database allows to uncover long-term paths of relations underlying the position of an actor in the elite. This can result, for example, from increasing power accumulation across generations within the same family. This is the case, for example, of the local-merchant-banker Mariano Arlotta, son of Antonio, also a powerful merchant-banker in the Bourbon period and important member of the Naples Chamber of Commerce. Post-Unification, Mariano became a primary banker and a powerful politician both at local and national level (Naples city councilor and deputy of the Italian Parliament), then followed by his nephew Enrico who, in the first decades of the twentieth century, became Ministry of Finance and vice-President of the Italian Parliament. Power can also result from self-constructed paths of relations rooted in the Bourbon period and flourishing post-Unification. This is the case of the fairly unknown Neapolitan businessman Domenico Gallotti, of a modest family of shopkeepers. He climbed the ranks of the Bourbon administration thanks to the closeness to the Sicilian lieutenant Paolo Ruffo (Principe di Castelcicala), who also introduced him to the world of high diplomacy and finance during his exile in II Empire Paris. Following Unification, thus, 


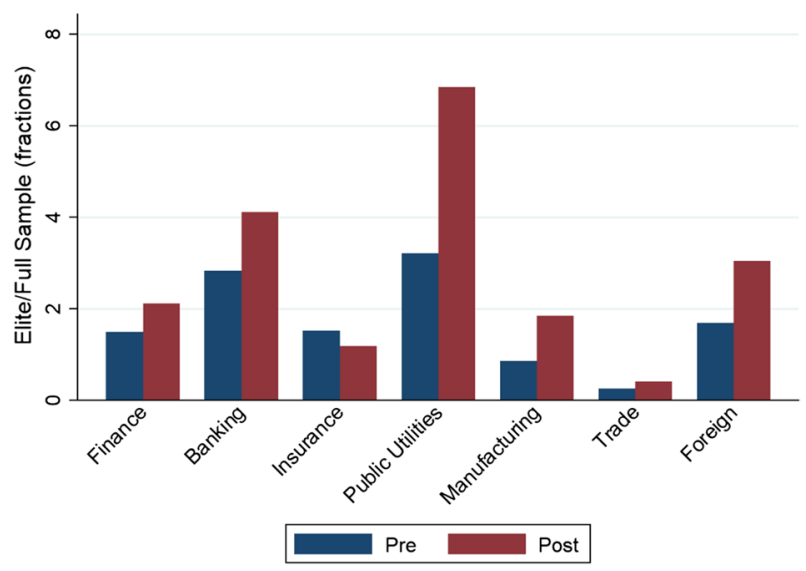

Fig. 4 Composition of the elite group

he became the hub of a dense and entangled network of business, financial, political and personal relationships between Naples, Paris and Rome. He played a key role in the creation of the first southern credit-mobilier-type bank (Banca Napoletana then Credito Meridionale) and of a wide range of companies (e.g., railway, naval transportation, telephone communication, banking, financial firms), also entering local politics as a city councilor (Schisani 2019). ${ }^{7}$

\subsubsection{Economic sectors and nationality}

Looking at the data in Fig. 4, for the pre-Unification period, and compared to the full sample, this group of highly connected actors is characterized by an over-representation of individuals involved in finance (the proportion being 1.5 times the one in the full sample) and public utilities and transport (3.21 times) and an under-representation of the trade sector and of the manufacturing sector $(0.25$ and 0.86 , respectively). Within the Finance sector, although relatively more actors are involved in insurance than in banking both in the elite and in the full sample, the degree of overrepresentation is larger for banking (2.83 times against 1.52). Last, a sizeable percentage, indeed more than $50 \%$, of the elite is formed by foreign actors (1.69 times the fraction in the full sample). We can explain these results with the business structure of the south in the Bourbon period. Industrial initiatives were of small/medium scale mainly organized in form of family-based general partnerships (e.g., Guppy, Pattison, Carlo Lefebvre), while the largest joint stock companies, essentially in textile and iron industry, were mainly state owned enterprises (SOE) (i.e., San Leucio, Pietrarsa, Mongiana, Capodimonte, etc.). The core of the business network was formed by large insurance companies, naturally related to trade activities but mainly active in banking and financial speculation, in which the narrow community of the

\footnotetext{
7 These last examples suggest a fruitful integrated approach in the study of elites, that merges the quantitative analysis based on Social Networks with more qualitative prosopographical information (Lemercier and Picard 2012; Fellman 2014; Cassis and Telesca 2018).
} 
local merchant bankers established ties by co-shareholding and interlocking directorates. This was the despecialized big business to which they had switched since the mid 1820s, after Karl Rothschild had obtained the monopoly of public debt of the Bourbon kingdom (1821) excluding them from that traditional form of speculation (Schisani 2001, 2010). The relevance of banking in the elite group is explained mainly by the interest in Naples by foreign bankers and financiers, linked to primary foreign banking institutions and public utilities. This group is formed by individuals who might or might not be physically present in Naples (and indeed, many were not) but who had invested in companies that operated in the city. Particularly, we refer to the two French groups, one headed by the Pereires (with Charles Laffitte, Charles Mallet, Benoit Fould, Jean Henry Hottinguer) that had climbed the local Banca Fruttuaria to realize the unsuccessful project of the Naples Crédit Mobilier (1856) and the other one headed by Basile Parent (with Charles Blount, Gustave Delahante, Raffaele de Ferrari Duc de Galliera, Benoit C.A. Chatelus) that had been awarded the unrealized contract for Adriatic railway construction (Società per la rete di ferrovie da Napoli al Mare Adriatico) (1860) just before the fall of the Bourbon monarchy.

For the post-Unification period, we note that the structure of the elite remains quite similar to the pre-Unification period, with three important changes. First, there is a movement within the finance sector away from traditional insurance toward banking, which is reflected in a larger percentage of the sample involved in the latter, and in a jump of the over-representation in the elite (4.11 times the fraction in the population). Second, there is a doubling of the over-representation of public utilities actors (from 3.21 to 6.84). Third, although the percentage of elite actors involved in manufacturing firms remains lower than in the two leading sectors, it also increases relative to pre-Unification, becoming over-represented in the elite (1.84 times the percentage in the full sample). This is explained by the systemic effects of the Unification on the local economy after the inclusion of the south in the newborn state. Infrastructural plans (transport and public utilities) became central in the economic policies of the liberal governments. Like other capital cities of the pre-unification states, Naples_-now peripheral but still the biggest Italian city in terms of inhabitants $(447,075 \text { people })^{8}$ — underwent dramatic transformations. Trying to maintain its centrality in the south, urban planning and public utilities projects were promoted on a large-scale (i.e., railways, harbor, expansion both of eastern and western areas of the city, public utilities such as lighting, water supply and distribution, and urban transportation $)^{9}$ to transform the old Bourbon capital in the modern "networked city" (Tarr and Dupuy 1988) of the south. The local financial system, as well, was deeply affected by Unification. Finally, freed from the protectionist restraints of the Bourbons, thanks to the trade and capital openness of the new Italian liberal

\footnotetext{
${ }^{8}$ Censimento generale della popolazione del Regno d'Italia (al 31 dicembre 1861), Ministero di Industria e Commercio, Direzione di Statistica, Stamperia Reale, 1863, 74.

${ }^{9}$ Collezione delle leggi e de' decreti reali del Regno delle Due Sicilie (Laws and Decrees of the Kingdom of the Two Sicilies), Decree n. 676, 25 February 1860; Decree n. 809, 28 April 1860, Stamperia Reale, Naples 1860; Collezione delle leggi e decreti emanati nelle Provincie Continentali dell'Italia meridionale (Laws and Decrees for the Southern Italy Provinces), Decree n. 14, 1 July 1860; Decree n. 24, 6 July 1860; Decree n. 129, 24 August 1860, Stamperia Reale, Naples 1860.
} 
governments, and relieved of the Rothschilds' banking monopoly (1863), Naples and the south opened to foreign capital which massively arrived attracted by the broad-ranging infrastructural projects. The core of financial activity changed from despecialization typical of merchant banking to more specialized banking and insurance operational practices and, in 1870, a credit-mobilier-type bank was finally formed in Naples (Banca Napoletana). On the other hand, in the manufacturing sector, the development of private enterprises, which substituted the Bourbon SOEs, never scraped the prevailing tertiary vocation of Naples and its business elite.

In these changing dynamics, the local business elite bridged past practices and new opportunities. A telling example from Table 8 in the Appendix is baron Luigi Bonaventura Balsamo (dei Marchesi di Specchia), a Naples-based Apulian aristocrat from Gallipoli, in the elite before and after Unification. Socially classified as a merchant (negoziante) in the pre-unitarian period, he sat in primary insurance companies (1851) (Compagnia rassicuratrice dai rischi del mare) and was among the founders of the Naples gas company (1841) (Compagnie Pouchain). In the post-Unification period, after having become a city Councilor in Naples (1861) and being appointed as president of the local branch of the main Italian issuing bank, the Banca Nazionale (1861), he became the mean through which the French group headed by Basile Parent (e.g., Adrien Lebeuf de Montgermont, Eugene Blin, Vincent Dubochet, Auguste Dassier) furtherly rooted in Naples by creating, in 1862 the Paris-based Naples gas company (Compagnie Napolitaine d'Éclairage et de Chauffage par le gaz).

\subsection{Estimating the determinants of network power}

In this section, we study the effects of Unification on the determinants of network power in quantitative terms. In order to estimate the determinants of network power and its change over Unification, we estimate variants of the following full model:

$$
\begin{aligned}
& \text { Power } \text { Index }_{i t}=\alpha_{0}+\alpha_{1} \text { Time }_{i}+\delta_{0} \text { Elite }_{i t}+\delta_{1} \text { Time }_{i} \times \text { Elite }_{i t} \\
& +\sum_{j \in S} \beta_{0 j} D_{i j t}+\sum_{j \in S} \beta_{1 j} \text { Time }_{i} \times D_{i t j}+\gamma_{0} \text { Foreign }_{i t}+\gamma_{1} \text { Time }_{i} \times \text { Foreign }_{i t} \\
& +\theta_{0} \text { Politician }(\mathrm{POST})_{i}+\theta_{1} \text { Time }_{i} \times \text { Politician }(\mathrm{POST})_{i} \\
& +\sum_{j \in S^{\prime}} \rho_{0 j} D_{i j t} \times \text { Elite }_{i t}+\sum_{j \in S^{\prime}} \rho_{1 j} D_{i j t} \times \text { Elite }_{i t} \times \text { Time }_{i} \\
& +\operatorname{Diff}_{i t}+\epsilon_{i t}
\end{aligned}
$$

where all the explanatory variables are dummies. Time ${ }_{i}=1$ indicates whether the observation refers to the POST-Unification network, $D_{i j t}=1$ if individual $i$ is linked at time $t$ to at least one firm that operates in sector $j \in S$, where the set depends on the regression we run. As a first step, we consider the aggregate sectors finance, public utilities and transport, manufacturing, trade. Then, we disaggregate the finance sector in bank-insurance-finance(other), and the trade sector in International Trade-Trade(other). Foreign $i t=1$ if he/she is not national of the post-Unification Kingdom of Italy at time $t$. Politician $(\mathrm{POST})_{i}=1$ if he/she had a political role either at the local level (member of the City Council of Naples) or at the national level 
(Member of the Parliament or a Minister in the National Government of the Kingdom of Italy) in the post-Unification period. In the last step, we include interactions of elite with a subset $S^{\prime}$ of sectors. In all regressions, we control for differentiation with Diff $_{i t}=1$ if at time $t$ individual $i$ is linked to a firm that operates in more than one sector or is linked to different firms that operate in different sectors. Note that all the dummies refer to attributes that an actor has at time $t$, thus their value might change over Unification, except the Politician dummy. Note also that with this model, we test for the significance of differences in difference (the coefficients with subscripts 1 in the regression) for all the variables at the same time. We proceed progressively by running several regressions. In all of them, the dummies for the elite, nationality, politics and the interactions with time that allow to study the differences in difference are present. In the first regression, we use aggregate sectors and no interactions of sectors with other variables. In the second regression, we disaggregate the finance and trade sector with still no interactions. In the third regression, we run the full model of Eq. (2), considering only the interactions of disaggregated financial sectors with the dummy elite, and thus we allow for differential effects based on being part of elite and being involved in finance. We estimate the first two models both on the unbalanced panel that is our full sample, and on the balanced panel of actors present before and after Unification, while the third model is estimated only on the full sample.

In Tables 4 and 5, we report the average marginal effects of each dummy variable on the power index, both pre- and post-Unification (first four columns) and their post-pre difference (last two columns). The first four columns are thus estimates of the difference between the average power index for individuals having and not having that specific characteristic, and the last two columns are estimates of the change in these differences over Unification. In these tables, Columns (1), (3) and (5) refer to the regression on the full sample, Columns (2), (4) and (6) refer to the regression on the subsample of actors present before and after Unification. In Table 4, we report the results for the regressions using the aggregate sectors Finance and Trade, while in Table 5, we disaggregate in the subsectors bank, insurance and finance (other), and trade international, trade (other), respectively. In Table 7, we report the estimates for the model with interactions. In Table 10, in the Appendix, we add interactions between (disaggregated) financial sectors and the dummy Elite. ${ }^{10}$

In all specifications, both before and after Unification, we find a strong positive effect of being in the Elite group we identified in the previous Section. As explained above, this group can be taken as representative of the ruling elite of the Naples' business environment. Notably, the size of the effect is roughly the same pre and post (the estimated difference is either positive but small or slightly negative but not significant). This is true both in the full sample and in the restricted subsample of actors surviving Unification. This can be taken as evidence that Unification did not bring about a significant change in the power of the ruling elite of the Neapolitan business hierarchy.

\footnotetext{
${ }_{10}$ In Table 9 in the Appendix we report the full results of the regressions for the full sample ( 1 and 3 ) and for the subsample of 620 actors that are present both before and after Unification (2 and 4). In Table 10 we report the results of the regression that includes the interactions between (disaggregated) financial sectors and the dummy Elite.
} 
Table 4 Difference-in-difference estimates of the effects of unification on the determinants of network power (aggregate sectors)

\begin{tabular}{|c|c|c|c|c|c|c|}
\hline & \multicolumn{2}{|l|}{ PRE } & \multicolumn{2}{|l|}{ POST } & \multicolumn{2}{|l|}{ POST-PRE } \\
\hline & (1) & (2) & (3) & (4) & (5) & (6) \\
\hline Elite & $\begin{array}{l}1.853 * * * \\
(0.116)\end{array}$ & $\begin{array}{l}1.885^{* * * *} \\
(0.167)\end{array}$ & $\begin{array}{l}2.189 * * * \\
(0.134)\end{array}$ & $\begin{array}{l}1.625^{* * *} \\
(0.219)\end{array}$ & $\begin{array}{l}0.336^{*} \\
(0.176)\end{array}$ & $\begin{array}{l}-0.260 \\
(0.277)\end{array}$ \\
\hline Finance & $\begin{array}{l}1.945^{* * * *} \\
(0.091)\end{array}$ & $\begin{array}{l}2.785^{* * * *} \\
(0.187)\end{array}$ & $\begin{array}{l}0.993 * * * \\
(0.073)\end{array}$ & $\begin{array}{l}2.585^{* * * *} \\
(0.218)\end{array}$ & $\begin{array}{l}-0.952 * * * \\
(0.101)\end{array}$ & $\begin{array}{l}-0.200 \\
(0.207)\end{array}$ \\
\hline Publ. util. \&transp. & $\begin{array}{l}1.264 * * * \\
(0.108)\end{array}$ & $\begin{array}{l}1.907 * * * \\
(0.214)\end{array}$ & $\begin{array}{l}0.443 * * * \\
(0.092)\end{array}$ & $\begin{array}{l}1.620 * * * \\
(0.237)\end{array}$ & $\begin{array}{l}-0.821 * * * \\
(0.124)\end{array}$ & $\begin{array}{l}-0.287 \\
(0.247)\end{array}$ \\
\hline Manufacturing & $\begin{array}{l}-0.285^{* * *} \\
(0.098)\end{array}$ & $\begin{array}{l}0.447 * * \\
(0.214)\end{array}$ & $\begin{array}{l}-0.408^{* * * *} \\
(0.083)\end{array}$ & $\begin{array}{l}1.066^{* * * *} \\
(0.227)\end{array}$ & $\begin{array}{l}-0.123 \\
(0.106)\end{array}$ & $\begin{array}{l}0.618 * * * \\
(0.204)\end{array}$ \\
\hline Trade & $\begin{array}{l}-0.878 * * * \\
(0.097)\end{array}$ & $\begin{array}{l}-0.279 \\
(0.199)\end{array}$ & $\begin{array}{l}-1.360^{* * *} \\
(0.079)\end{array}$ & $\begin{array}{l}-0.366 \\
(0.233)\end{array}$ & $\begin{array}{l}-0.482 * * * \\
(0.110)\end{array}$ & $\begin{array}{l}-0.087 \\
(0.246)\end{array}$ \\
\hline Foreign & $\begin{array}{l}-0.511^{* * *} \\
(0.072)\end{array}$ & $\begin{array}{l}-0.722^{* * *} \\
(0.132)\end{array}$ & $\begin{array}{l}-0.745^{* * *} \\
(0.054)\end{array}$ & $\begin{array}{l}-0.613^{* * * *} \\
(0.143)\end{array}$ & $\begin{array}{l}-0.235^{* * * *} \\
(0.090)\end{array}$ & $\begin{array}{l}0.109 \\
(0.194)\end{array}$ \\
\hline Politician POST & $\begin{array}{l}0.056 \\
(0.187)\end{array}$ & $\begin{array}{l}0.120 \\
(0.263)\end{array}$ & $\begin{array}{l}0.534 * * * \\
(0.112)\end{array}$ & $\begin{array}{l}0.645 * * \\
(0.257)\end{array}$ & $\begin{array}{l}0.478^{* * *} \\
(0.218)\end{array}$ & $\begin{array}{l}0.526 \\
(0.368)\end{array}$ \\
\hline Observations & 6196 & 1240 & 6196 & 1240 & 6196 & 1240 \\
\hline $\mathrm{R}^{2}$ & 0.431 & 0.575 & 0.431 & 0.575 & 0.431 & 0.575 \\
\hline
\end{tabular}

For all regressions, the dependent variable is the power index. Columns (1), (3), (5) are derived from the regression on the full sample, corresponding to column (1) in Table 9 in Appendix; the total of 6196 observations is an unbalanced panel of 1796 actors for PRE and 4400 for POST. Columns (2), (4), (6) are derived from the regression on the subsample of actors present before and after unification, corresponding to column (3) in Table 9 in Appendix; it is a balanced panel of 620 actors present PRE and POST

Robust standard error in parenthesis. $* * * p<0.01 ; * * p<0.05 ; * p<0.1$

For the sectoral analysis, in Table 4, we find that in both Pre-Unification samples involvement in Finance and Public Utilities and Transport firms yields a large positive significant effect, while involvement in Manufacturing or Trade firms yields a positive but smaller or a negative effect. There exists a clear ranking of more connected individuals by sector of activity, with Finance on top, followed by Public Utilities and Transport, Manufacturing and Trade in order of relevance.

To what extent does the sectoral anatomy of business network power change after Unification? The results in the last two columns of Table 4 show the change in the size of the coefficients after Unification. In column (5), we observe that in the full sample the magnitude of the effects on the top two sectors, Finance and Public Utilities and Transport, decreases more than two bottom sectors, Manufacturing and Trade. Thus, the distance between the top and bottom sector decreases, without however changing their relative ranking. Comparing to the coefficients in column (6), we note that in the restricted subsample, the changes are smaller and generally not significant, except for Manufacturing, and again the ranking does not change over Unification. This is confirmed by the results in columns (3) and (4) that show the size of the coefficients for the Post-Unification. Thus, both Pre- and Post-Unification we find that Financial (mostly) and Public Utilities and Transport firms were the hubs 
Table 5 Difference-in-difference estimates of the effects of unification on the determinants of network power (disaggregated sectors)

\begin{tabular}{|c|c|c|c|c|c|c|}
\hline & \multicolumn{2}{|l|}{ PRE } & \multicolumn{2}{|l|}{ POST } & \multicolumn{2}{|l|}{ POST-PRE } \\
\hline & (1) & (2) & (3) & (4) & (5) & (6) \\
\hline Elite & $\begin{array}{l}1.648^{* * * *} \\
(0.123)\end{array}$ & $\begin{array}{l}1.474 * * * \\
(0.189)\end{array}$ & $\begin{array}{l}1.966 \text { *** } \\
(0.135)\end{array}$ & $\begin{array}{l}1.701 * * * \\
(0.198)\end{array}$ & $\begin{array}{l}0.318^{*} \\
(0.182)\end{array}$ & $\begin{array}{l}0.226 \\
(0.275)\end{array}$ \\
\hline Bank & $\begin{array}{l}0.159 \\
(0.103)\end{array}$ & $\begin{array}{l}0.392 * * \\
(0.182)\end{array}$ & $\begin{array}{l}1.009 * * * \\
(0.076)\end{array}$ & $\begin{array}{l}1.313 * * * \\
(0.191)\end{array}$ & $\begin{array}{l}0.850^{* * * *} \\
(0.114)\end{array}$ & $\begin{array}{l}0.922 * * * \\
(0.212)\end{array}$ \\
\hline Insurance & $\begin{array}{l}2.393 * * * \\
(0.085)\end{array}$ & $\begin{array}{l}3.090 * * * \\
(0.160)\end{array}$ & $\begin{array}{l}0.945 * * * \\
(0.072)\end{array}$ & $\begin{array}{l}2.596 * * * \\
(0.184)\end{array}$ & $\begin{array}{l}-1.448 * * * \\
(0.103)\end{array}$ & $\begin{array}{l}-0.494^{* *} \\
(0.217)\end{array}$ \\
\hline Finance (other) & $\begin{array}{l}0.605 * * * \\
(0.132)\end{array}$ & $\begin{array}{l}0.836 * * * \\
(0.236)\end{array}$ & $\begin{array}{l}0.105 \\
(0.119)\end{array}$ & $\begin{array}{l}1.379 * * * \\
(0.237)\end{array}$ & $\begin{array}{l}-0.500^{* * *} \\
(0.161)\end{array}$ & $\begin{array}{l}0.543 * \\
(0.281)\end{array}$ \\
\hline Publ. util. \& transp. & $\begin{array}{l}1.332 * * * \\
(0.104)\end{array}$ & $\begin{array}{l}1.678^{* * * *} \\
(0.202)\end{array}$ & $\begin{array}{l}0.310^{* * *} \\
(0.089)\end{array}$ & $\begin{array}{l}1.187 * * * \\
(0.212)\end{array}$ & $\begin{array}{l}-1.022 * * * \\
(0.122)\end{array}$ & $\begin{array}{l}-0.490^{*} \\
(0.251)\end{array}$ \\
\hline Manufacturing & $\begin{array}{l}-0.263 * * * \\
(0.094)\end{array}$ & $\begin{array}{l}0.191 \\
(0.177)\end{array}$ & $\begin{array}{l}-0.491 * * * \\
(0.080)\end{array}$ & $\begin{array}{l}0.606 \text { *** } \\
(0.203)\end{array}$ & $\begin{array}{l}-0.228 \\
(0.105)\end{array}$ & $\begin{array}{l}0.415^{* *} \\
(0.204)\end{array}$ \\
\hline International trade & $\begin{array}{l}-0.759^{* * * *} \\
(0.110)\end{array}$ & $\begin{array}{l}-0.278 \\
(0.189)\end{array}$ & $\begin{array}{l}-2.030 * * * \\
(0.095)\end{array}$ & $\begin{array}{l}-0.566 \\
(0.304)\end{array}$ & $\begin{array}{l}-1.271 * * * \\
(0.137)\end{array}$ & $\begin{array}{l}-0.288 \\
(0.334)\end{array}$ \\
\hline Trade (other) & $\begin{array}{l}-0.733^{* * *} \\
(0.088)\end{array}$ & $\begin{array}{l}-0.431 \\
(0.168)\end{array}$ & $\begin{array}{l}-1.337 * * * \\
(0.080)\end{array}$ & $\begin{array}{l}-0.757 * * * \\
(0.198)\end{array}$ & $\begin{array}{l}-0.604 * * * \\
(0.104)\end{array}$ & $\begin{array}{l}-0.326 \\
(0.219)\end{array}$ \\
\hline Foreign & $\begin{array}{l}-0.111^{*} \\
(0.063)\end{array}$ & $\begin{array}{l}-0.068 \\
(0.113)\end{array}$ & $\begin{array}{l}-0.701 * * * \\
(0.055)\end{array}$ & $\begin{array}{l}-0.133 \\
(0.152)\end{array}$ & $\begin{array}{l}-0.590^{* * * *} \\
(0.083)\end{array}$ & $\begin{array}{l}-0.065 \\
(0.189)\end{array}$ \\
\hline Politician POST & $\begin{array}{l}0.079 \\
(0.158)\end{array}$ & $\begin{array}{l}0.149 \\
(0.214)\end{array}$ & $\begin{array}{l}0.445 * * * \\
(0.110)\end{array}$ & $\begin{array}{l}0.316 \\
(0.241)\end{array}$ & $\begin{array}{l}0.366^{*} \\
(0.193)\end{array}$ & $\begin{array}{l}0.166 \\
(0.322)\end{array}$ \\
\hline Observations & 6196 & 1240 & 6196 & 1240 & 6196 & 1240 \\
\hline $\mathrm{R}^{2}$ & 0.468 & 0.660 & 0.468 & 0.660 & 0.468 & 0.660 \\
\hline
\end{tabular}

For all regressions, the dependent variable is the power index. Columns (1), (3), (5) are derived from the regression on the full sample, corresponding to column (1) in Table 9 in Appendix; the total of 6196 observations is an unbalanced panel of 1796 actors for PRE and 4400 for POST. Columns (2), (4), (6) are derived from the regression on the subsample of actors present before and after unification, corresponding to column (3) in Table 9 in Appendix; it is a balanced panel of 620 actors present PRE and POST

Robust standard error in parenthesis. ${ }^{* * *} p<0.01 ; * * p<0.05 ; * p<0.1$

creating business network ties that allowed individuals to rise in prominence due to the power of their relationships. Manufacturing and especially Trade firms, although fairly present (Table 1), were definitely less important in creating business relationships, mainly due to the fact that they were smaller and mostly individual firms.

For what we have noted about the rise of public utilities in post-Unification Naples, the fall in the power index over Unification is a surprising result. However, it can be explained with the ownership structure of public utilities companies after Unification, which geared toward inter-firm cross-shareholding rather than on individual shareholding, according to the organizational development of big business in the Second Industrial Revolution (Cassis 1997). On the other hand, the increasing degree of over-representation in the elite of individuals involved in public utilities, not in contrast with the previous result, is explained with the presence in these 
companies of big linkers, entrepreneurs and bankers sitting in a number of primary large banks and large industrial or service companies that own shares in public utilities (e.g., the group headed by Basile Parent and Pierre Schaken).

In order to refine the sectorial analysis, in Table 5, we run the same regression on more disaggregate sectors. Specifically, to investigate further the change in the relevance of the Financial sector we disaggregate financial firms into Insurance, Banking and Finance (other). In addition, since Unification represented a drastic change in policy toward liberalization of international trade, one might conjecture that, within the Trade sector, firms that were and were not involved in International Trade were affected differently by the institutional change. Thus, we disaggregate the Trade sector in International Trade and Trade (other). ${ }^{11}$

The results show that the decrease in the index for the Financial sector in the aggregate regression masks a change in the relative importance, within the sector, of traditional Insurance over Banking, with the latter gaining relevance at the expense of the former. In the pre-Unification, traditional Insurance has the larger network power, while in post-Unification, we observe a rise in importance of Banking. In the full sample, the coefficient on Banking becomes similar in magnitude to the coefficient of Insurance. In the restricted subsample, like in the previous regression, the effect is more muted and post-Unification still Insurance has the largest network power.

Regarding the Trade sector, we note that Unification did not bring about a rise in network relevance of the International Trade sector, relative to all other sectors and even relative to other Trade firms. Actually, in the full sample, the negative effect on International Trade is larger than for other Trade. Thus, if anything, being involved in International Trade became after Unification less important for the relevance of an actor within the network. This is somewhat surprising, given the process of liberalization of trade that happened with Unification. However, it must also be noted that together with liberalization the city of Naples also lost its role as capital, and the port of Naples partly lost its centrality for trade routes. This can in part explain our results. Furthermore, our analysis is limited to the network relevance of actors active in a sector, and it does not say anything about the profitability of the sector itself. It might as well be that trade firms became less central but still be as, or even more, profitable.

The next topic we tackle is the role that foreign actors played in the Naples' business community. In the previous section, we noted that foreign actors made up a significant fraction of the elite group, with their fraction staying roughly constant over Unification. Moreover, foreigns were definitely over-represented in the elite compared to the full sample, with the degree of over-representation increasing over Unification, mostly due to the fact that after Unification foreigns were a smaller fraction of the full sample than before. Looking at the results in Table 5, we find that in the full pre-Unification sample on average, they have a smaller power index than nonforeign and this difference becomes more negative post-Unification. In the restricted subsample, this difference does not change. Thus, it seems that Unification did not cause a significant change in the presence of foreigns in the elite group, and at the same time, the negative effect on the power index increases in absolute value for the full sample and stays constant for the restricted subsample.

11 For the construction of this dummy, see footnote 9. 
Table 6 Network assortativity by nationality

\begin{tabular}{lll}
\hline & PRE & POST \\
\hline Non-foreign-non-foreign & 0.752 & 0.832 \\
Foreign-foreign & 0.132 & 0.067 \\
Foreign-non-foreign & 0.116 & 0.10 \\
Assortativity coefficient & 0.623 & 0.517 \\
\hline
\end{tabular}

Each cell of the first three rows contains the fraction of edges that link two vertices. The fourth row contains the assortativity coefficient (Newman 2003)

These seemingly contradictory results can be explained by the specific strategy that foreigns followed in coming to Naples. Before proposing our interpretation, in Table 6, we assess the degree of assortativity mixing between foreign and non-foreign actors. That is, the extent to which non-foreign and foreign actors prefer to form links with actors of their own group. In Table 6, we present the mixing matrices (in column form since in our context these matrices are symmetric) and the related assortativity coefficients. Each cell reports the fraction of edges that have the row characteristics (thus linking non-foreign to non-foreign, foreign to foreign and nonforeign to foreign). The assortativity coefficient summarizes the degree of assortative mixing in the network. It takes value $r=1$ for a perfectly assortative network, $r=0$ when there is no assortative mixing and $-1 \leq r=r_{\min }<0$ for a perfectly disassortative network (see Newman 2003). In both pre- and post-Unification, we find that the networks are strongly assortative, with the degree of assortative mixing only marginally decreasing over Unification. Thus, non-foreign (foreign) actors strongly prefer to form links to firms where other non-foreign (foreign) actors are present, thus firms organize around actors of the same nationality.

This evidence can be used to reconcile the above results on the effects of nationality on the power index. Foreign investors came to Naples mainly by forming firms with other foreign investors of the same nationality. We also know from our data that mostly these firms had their legal headquarters in their place of origin, where financial markets were already developed. This was the case, for example, of the most important public utilities, like the gas company (Compagnie Napolitaine pour le Chauffage et l'Eclairage par le gaz) that had its administrative headquarters in Paris (even if legally incorporated in Naples), or the London-based Naples Water Works or the tramways companies legally based in Belgium and France (Compagnie des tramways èlectriques de Castellammare de Stabia à Sorrente in Paris, Société anonyme des tramways napolitains (SATN) in Bruxelles, etc.). Since the average foreign investor linked mainly with other foreign investors of the same nationality, and since these are less numerous than non-foreign investors, on average, their power index is smaller than non-foreigns. However, to profitably gain access to local business, these communities needed the right connections, which could be obtained only by entering non-foreign central firms. These connections were generally established through few powerful investors sitting in the boards of these firms, who we mostly find in the elite group. At the same time, few key local individuals entered the boards or participated as shareholders of foreign established firms. Thus, rather than being integrated in the business community, the links between foreign and non-foreign firms were created by 
only a handful of key powerful actors, whose power did not decrease across Unification. To a more general extent, this is also true if we look beyond the elite group but in the restricted subsample of actors persisting Unification. Since this subsample is in itself formed by actors with a large power index both pre- and post-Unification, also in this subsample the power of foreign actors did not decrease.

Next, we move to study the effect of politics on network power. Unfortunately, we do not have data on the political bodies of pre-Unification Kingdom of the two Sicilies to perform the same kind of analysis that we did for sectors and nationality. However, we do have data on the members of the Parliament and Government of post-Unification Kingdom of Italy and the components of the Naples' City Council, which we recorded in the dummy politician. We first note that the connection between politics and business in post-Unification Naples was tight. For example, of the 72 members in the first Naples' City Council in 1861, 38 are also present in our database, thus they have some connection to business. At the same time, in our database, in the post-Unification 20-year period, 110 actors had been part of the Naples' City Council at least once, 107 of the Camera dei Deputati, and we also find 16 actors which were at some point part of the national government. Overall, we find 198 distinct individuals who were at some point part of one of these political bodies. The results in Table 5 show a positive coefficient in post-Unification, significant in the full sample and borderline in the restricted subsample (mainly due to a larger standard error). In pre-Unification, the coefficient is nearly zero and not significant. Thus, participation in politics after Unification is positively associated with business network power, but it seems that this power is acquired after Unification rather than being already present before 1861 .

Given the results of the model in Table 5, as a last step, we test the hypothesis that finance played a crucial role in determining the persistence of the southern elites, i.e., financial elites preserved their power more than others simply belonging to the business elite. To do that, we introduce in our model the interactions between the disaggregated financial sector dummies (banks, insurances and other financial activities) and the dummy for being part of the elite. We run the model on the full sample in order to have enough observations to estimate all the new interaction effects.

In Table $7^{12}$ [and Table $10^{13}$ in the Appendix], we report the results of this model compared with the above discussed model without interactions. For pre-Unification [Table 7 columns (1) and (2)], first of all we notice that the estimated average effects in the two models are substantially similar both in terms of magnitude and significance. The results confirm our previous reading that attributed a key role to being part of elite and of all financial sectors, with a prominent effect of insurances compared to banks and other financial activities. In addition, all the interaction terms are significant: being elite and involved in any financial sectors at the same time increases the power compared to being involved only in the financial sector. This implies that the power of elite positively affects the power gained by finance, especially in the insurance sector.

Moving to the effect of Unification [Table 7 columns (5) and (6), and columns (3) and (4)], we first observe that coefficients on the sector dummies are affected by

\footnotetext{
12 Note that columns (1) (3) and (5) are the same of Table 5 columns (1) (3) and (5). We report again these results to facilitate readers in comparing the model results.

13 Note that column (1) is the same of Table 9 column (2). We report it again to facilitate readers in comparing the model results.
} 
Unification in the same direction as they were affected in the model without interaction terms. The main result is that the average change of the coefficient for elite becomes negative and not significant, i.e., the average power of elite does not change significantly over Unification remaining substantially stable. This shift is compensated by the positive and significant effect of the average change in the interaction term between elite and bank. Thus, the involvement in banking sector confirms and strengthens the power of elite. As for the other interactions, insurance and finance (other) with elite show negative coefficients, reinforcing our previous finding on the decreasing power of these sectors that however still remain quite high on average. One way to read these results is that Unification marked a drastic change in the insurance sector. Marine insurances, which had been the core of the Neapolitan business environment in preUnification, dramatically lost importance in post-Unification, crushed by the competition of the subsidiaries of large foreign insurance that had entered the Italian market after the liberal turn. In order to preserve their power in spite of the underlying institutional change, elites were led to a functional change away from insurance toward banking moving within the financial sector, also according to the progressive specialization of the financial activity at an international level (Cameron 1961).

\section{Concluding remarks}

In this article, we examine the implications of the institutional shock of Italian Unification on the power of southern economic elites. For the first time in the literature, we use original microdata on individual economic actors involved in the Naples entrepreneurial system in the nineteenth century to assess the existence of a ruling business elite and model its persisting power in the face of the 1861 institutional change. We take the analysis as representative for the socioeconomic dynamics of the entire continental south of Italy.

Methodologically, our work adds more specific evidence to the recent quantitative analyses that infer the existence of privileged elites from indirect aggregate measures such as illiteracy and primary enrollment rates (Felice 2018). We offer a clear-cut definition of the southern dominant groups over Unification, based on quantitative measures of business network power. Our results also allow to overcome the topos of a semi-feudal agrarian and aristocratic elite (Franchetti and Sonnino 1877; Dorso 1925; Gramsci 1935) and to refine the blurred concept of a southern dominant "financial oligarchy" from the socio-historical literature (Davis 1979).

Our paper provides strong evidence that the power of southern (Neapolitan) elites survived Unification. The emerging of market forces fostered by the post-Unification liberal turn, differently from what expected according to the interest group theory of financial development (Rajan and Zingales 2003), largely failed in disrupting the monopolistic power of the local incumbents.

In our analysis, two elements explain power continuity over the Unification: the strong relationships that the elites established with powerful foreign actors and their capacity to keep strong relations with politics. When potential foreign competitors arrived in Naples, attracted by the wide-ranging infrastructural plans promoted by the liberal governments of the new nation-state, local elites consolidated and increased their power, acting as the 
Table 7 Difference-in-difference estimates of the effects of unification on the determinants of network power without and with interactions between elite and financial sector

\begin{tabular}{|c|c|c|c|c|c|c|}
\hline & \multicolumn{2}{|l|}{ PRE } & \multicolumn{2}{|l|}{ POST } & \multicolumn{2}{|l|}{ POST-PRE } \\
\hline & (1) & (2) & (3) & (4) & (5) & $(6)$ \\
\hline Elite & $\begin{array}{l}1.648 * * * \\
(0.123)\end{array}$ & $\begin{array}{l}2.549 * * * \\
(0.179)\end{array}$ & $\begin{array}{l}1.966^{* * * *} \\
(0.135)\end{array}$ & $\begin{array}{l}2.408 * * * \\
(0.313)\end{array}$ & $\begin{array}{l}0.318^{*} \\
(0.182)\end{array}$ & $\begin{array}{l}-0.141 \\
(0.360)\end{array}$ \\
\hline Bank & $\begin{array}{l}0.159 \\
(0.103)\end{array}$ & $\begin{array}{l}0.272 * * \\
(0.109)\end{array}$ & $\begin{array}{l}1.009 * * * \\
(0.076)\end{array}$ & $\begin{array}{l}1.040 * * * \\
(0.077)\end{array}$ & $\begin{array}{l}0.850 * * * \\
(0.114)\end{array}$ & $\begin{array}{l}0.768^{* * *} \\
(0.120)\end{array}$ \\
\hline Insurance & $\begin{array}{l}2.393 * * * \\
(0.085)\end{array}$ & $\begin{array}{l}2.485 * * * \\
(0.083)\end{array}$ & $\begin{array}{l}0.945^{* * * *} \\
(0.072)\end{array}$ & $\begin{array}{l}0.940 * * * \\
(0.073)\end{array}$ & $\begin{array}{l}-1.448 * * * \\
(0.103)\end{array}$ & $\begin{array}{l}-1.545^{* * *} \\
(0.102)\end{array}$ \\
\hline Finance (other) & $\begin{array}{l}0.605 * * * \\
(0.132)\end{array}$ & $\begin{array}{l}0.627 * * * \\
(0.131)\end{array}$ & $\begin{array}{l}0.105 \\
(0.119)\end{array}$ & $\begin{array}{l}0.084 \\
(0.121)\end{array}$ & $\begin{array}{l}-0.500^{* * *} \\
(0.161)\end{array}$ & $\begin{array}{l}-0.543^{* * *} \\
(0.161)\end{array}$ \\
\hline Publ. util. \&transp. & $\begin{array}{l}1.332 * * * \\
(0.104)\end{array}$ & $\begin{array}{l}1.364 * * * \\
(0.099)\end{array}$ & $\begin{array}{l}0.310^{* * *} \\
(0.089)\end{array}$ & $\begin{array}{l}0.330 * * * \\
(0.090)\end{array}$ & $\begin{array}{l}-1.022 * * * \\
(0.122)\end{array}$ & $\begin{array}{l}-1.034 * * * \\
(0.118)\end{array}$ \\
\hline Manufacturing & $\begin{array}{l}-0.263^{* * *} \\
(0.094)\end{array}$ & $\begin{array}{l}-0.213 * * \\
(0.093)\end{array}$ & $\begin{array}{l}-0.491 * * * \\
(0.080)\end{array}$ & $\begin{array}{l}-0.484 * * * \\
(0.080)\end{array}$ & $\begin{array}{l}-0.228 \\
(0.105)\end{array}$ & $\begin{array}{l}-0.271^{* * * *} \\
(0.104)\end{array}$ \\
\hline International trade & $\begin{array}{l}-0.759 * * * \\
(0.110)\end{array}$ & $\begin{array}{l}-0.708 * * * \\
(0.109)\end{array}$ & $\begin{array}{l}-2.030^{* * *} \\
(0.095)\end{array}$ & $\begin{array}{l}-2.024 * * * \\
(0.096)\end{array}$ & $\begin{array}{l}-1.271 * * * \\
(0.137)\end{array}$ & $\begin{array}{l}-1.316^{* * * *} \\
(0.136)\end{array}$ \\
\hline Trade (other) & $\begin{array}{l}-0.733^{* * * *} \\
(0.088)\end{array}$ & $\begin{array}{l}-0.688 * * * \\
(0.086)\end{array}$ & $\begin{array}{l}-1.337 * * * \\
(0.080)\end{array}$ & $\begin{array}{l}-1.329 * * * \\
(0.080)\end{array}$ & $\begin{array}{l}-0.604 * * * \\
(0.104)\end{array}$ & $\begin{array}{l}-0,641 * * * \\
(0.102)\end{array}$ \\
\hline Foreign & $\begin{array}{l}-0.111^{*} \\
(0.063)\end{array}$ & $\begin{array}{l}-0.117^{*} \\
(0.063)\end{array}$ & $\begin{array}{l}-0.701^{* * * *} \\
(0.055)\end{array}$ & $\begin{array}{l}-0.698 * * * \\
(0.055)\end{array}$ & $\begin{array}{l}-0.590^{* * * *} \\
(0.083)\end{array}$ & $\begin{array}{l}-0.581 * * * \\
(0.083)\end{array}$ \\
\hline Politician POST & $\begin{array}{l}0.079 \\
(0.158)\end{array}$ & $\begin{array}{l}0.104 \\
(0.155)\end{array}$ & $\begin{array}{l}0.445^{* * * *} \\
(0.110)\end{array}$ & $\begin{array}{l}0.458^{* * * *} \\
(0.110)\end{array}$ & $\begin{array}{l}0.366^{*} \\
(0.193)\end{array}$ & $\begin{array}{l}0.354^{*} \\
(0.189)\end{array}$ \\
\hline Bank and elite & & $\begin{array}{l}1.929 * * * \\
(0.220)\end{array}$ & & $\begin{array}{l}2.661 * * * \\
(0.150)\end{array}$ & & $\begin{array}{l}0.732 * * * \\
(0.255)\end{array}$ \\
\hline Insurance and elite & & $\begin{array}{l}3.997 * * * \\
(0.167)\end{array}$ & & $\begin{array}{l}3.664 * * * \\
(0.298)\end{array}$ & & $\begin{array}{l}-0.333 \\
(0.338)\end{array}$ \\
\hline Finance (other) and elite & & $\begin{array}{l}3.869 * * * \\
(0.077)\end{array}$ & & $\begin{array}{l}2.790 * * * \\
(0.453)\end{array}$ & & $\begin{array}{l}-1.079 * * \\
(0.457)\end{array}$ \\
\hline Observations & 6196 & 6196 & 6196 & 6196 & 6196 & 6196 \\
\hline $\mathrm{R}^{2}$ & 0.468 & 0.471 & 0.468 & 0.471 & 0.468 & 0.471 \\
\hline
\end{tabular}

For all regressions, the dependent variable is the power index. Columns (1), (3), (5) are derived from the regression without interactions, corresponding to column (1) in Table 10 in Appendix; the total of 6196 observations is an unbalanced panel of 1796 actors for PRE and 4400 for POST. Columns (2), (4), (6) are derived from the regression on the same sample with the interaction between being part of the elite and being involved in financial activities (banks, insurances, and other financial activities), corresponding to column (2) in Table 10 in the Appendix

Robust standard error in parenthesis. ${ }^{* *} p<0.01 ; * * p<0.05 ; * p<0.1$

bridge between the south of Italy and the European core financial centers. Furthermore, we show that even in the face of the change in the political institutions, local economic elites were able to participate to the distribution of political power in the newborn state, at the local level and more importantly at the national level. 
We find that finance played a crucial role in determining the persistence of the southern elites. Network power was indeed mainly associated with participation in financial firms, both before and after Unification, which however brought about a functional change away from traditional insurance toward banking. As a further result, the sectoral analysis importantly shows that participation in public utilities also was associated with network power, with a weaker effect in the post-Unification wave of foreign investments in infrastructures. This is explained by the tendency of foreign actors to enter the core of the local network through only few powerful actors, but generally remaining tied to each other in the modern financial institutions of their home countries. This evidence is consistent with the funding dynamics that led foreign capital toward peripheries during the first globalization (Wilkins and Schröter 1998; Hausman et al. 2008; Colpan et al. 2010; Cassis 2010). Transnational business groups made it less necessary for foreign investors to have the finance service industry in the host country. This explains the role that business ties had in neutralizing the potentiality of the enlarged competition after 1861 to promote financial innovation in the south.

As a final conclusion, our paper provides an important contribution to the recent literature that insists on the "immutability" of socio-institutional structure and elites' strategies to explain the backwardness of southern Italy (Felice 2018; Felice and Vasta 2015). Although not in comparative terms with other Italian areas, our results are consistent with the "passive modernization" hypothesis, according to which southern elites accepted the challenge of modernization as long as it did not jeopardize their vested interests (Cafagna 1988; Felice 2013). More generally, the paper confirms that institutions prove to be important drivers of economic processes (North 1990; Acemoglu and Robinson 2012). The long-term business relations, rooted in the Bourbon period, the persisting lobbying power of the financial industry, the close collusive ties with potential foreign competitors and the closeness to politics after Unification are all elements that explain how the southern economic elites were able to crowd-out the change.

Acknowledgements The authors are indebted to Vladimir Batajeli for advice on the island algorithm and, in general, on the network approach to the topic of this paper. Furthermore, the authors warmly thank Francesca Caiazzo for her kind availability and assistance with data retrieving and checking. Comments by two anonymous referees have greatly improved the quality of the paper. All remaining errors are our own.

Open Access This article is licensed under a Creative Commons Attribution 4.0 International License, which permits use, sharing, adaptation, distribution and reproduction in any medium or format, as long as you give appropriate credit to the original author(s) and the source, provide a link to the Creative Commons licence, and indicate if changes were made. The images or other third party material in this article are included in the article's Creative Commons licence, unless indicated otherwise in a credit line to the material. If material is not included in the article's Creative Commons licence and your intended use is not permitted by statutory regulation or exceeds the permitted use, you will need to obtain permission directly from the copyright holder. To view a copy of this licence, visit http://creativecommons.org/licenses/by/4.0/

\section{Appendix}

See Tables 8, 9 and 10 . 


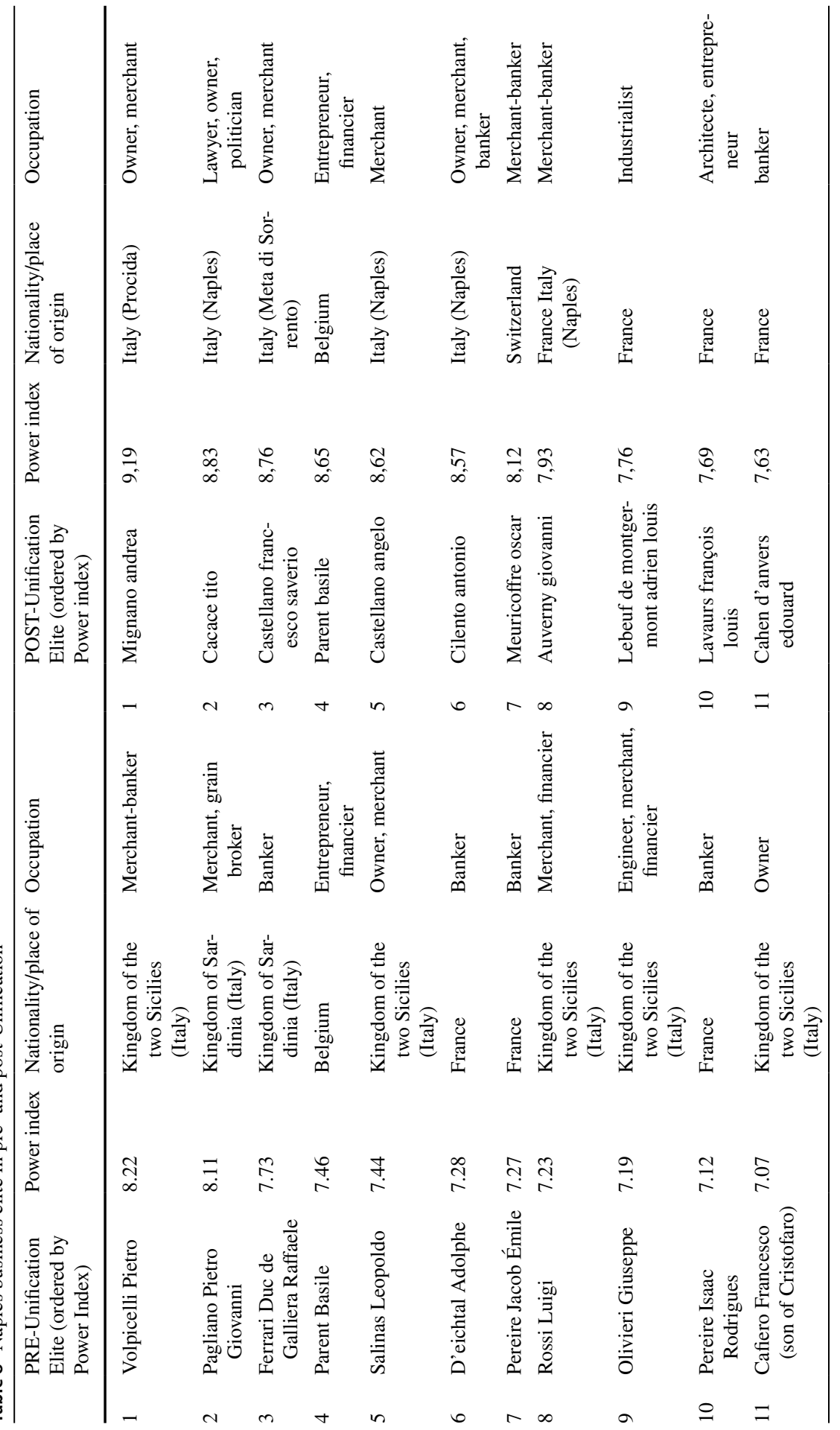




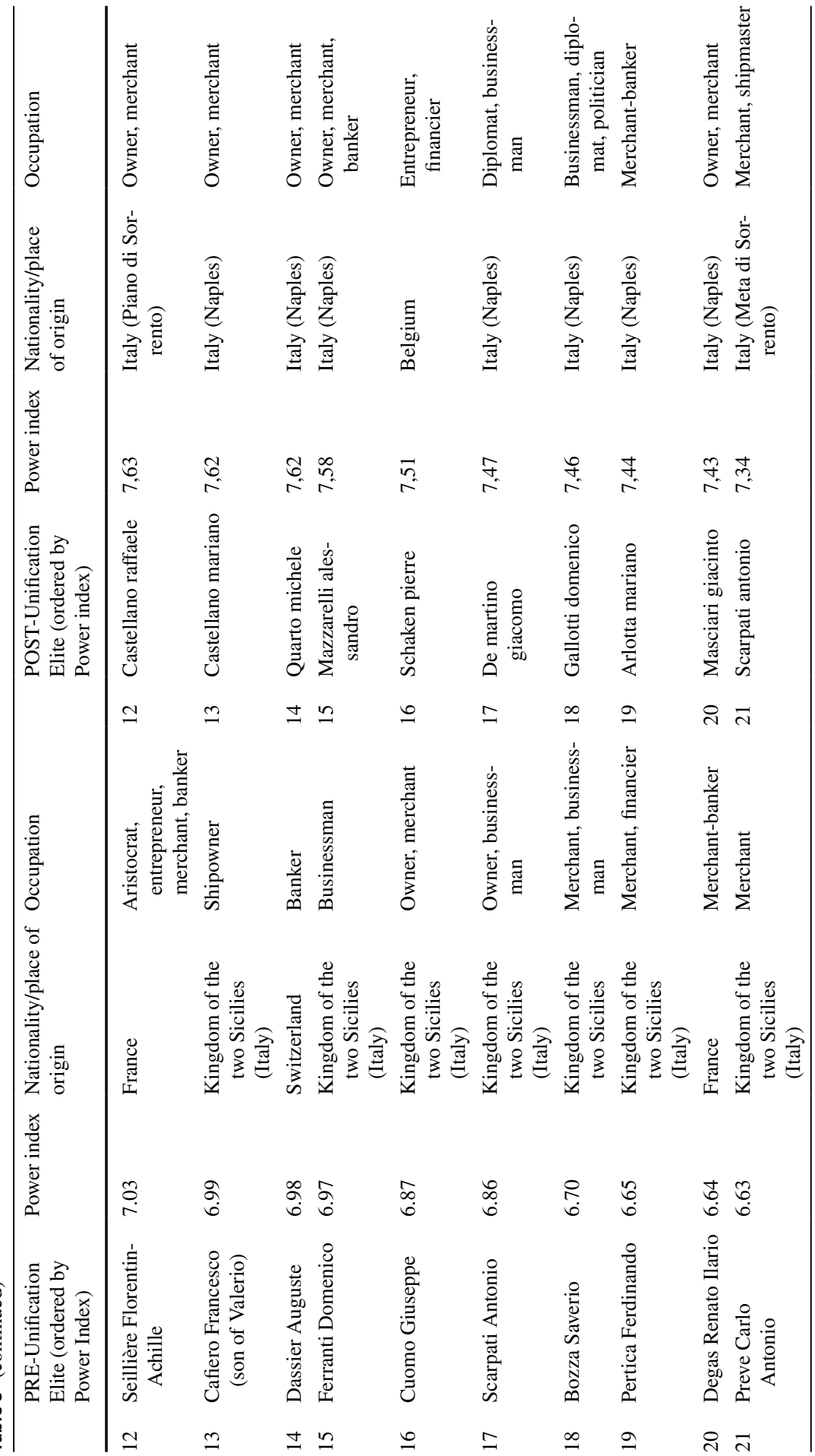




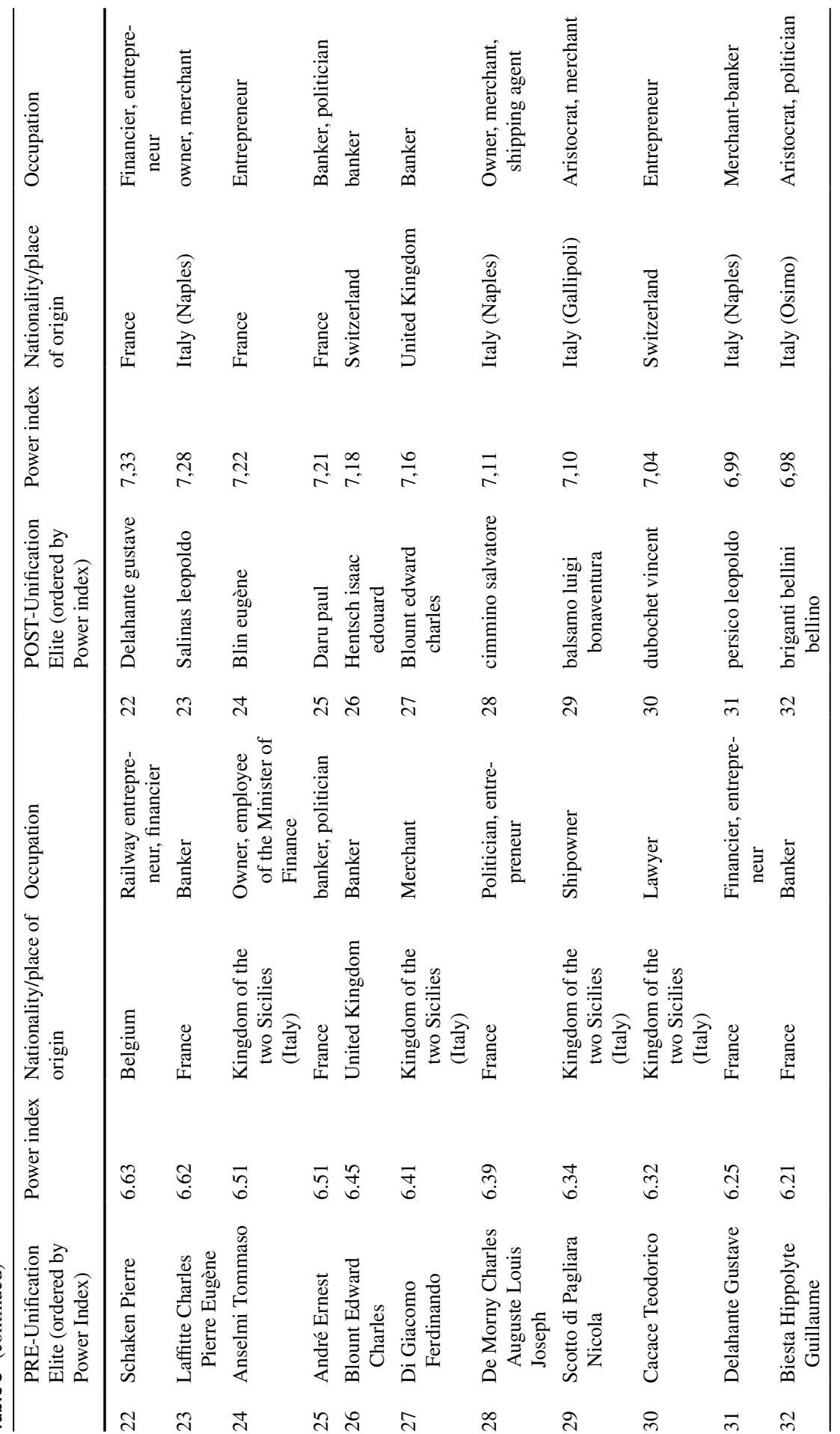




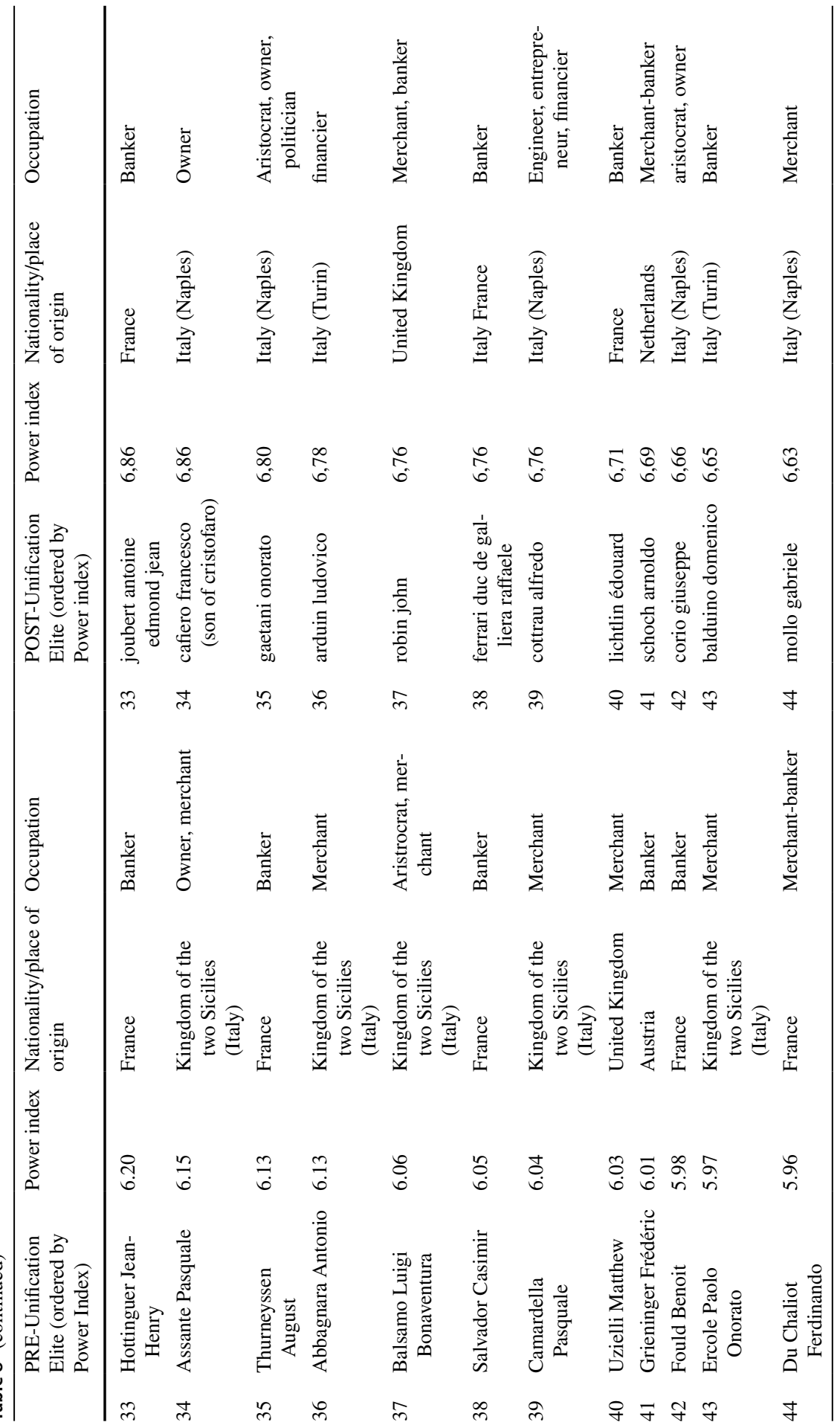




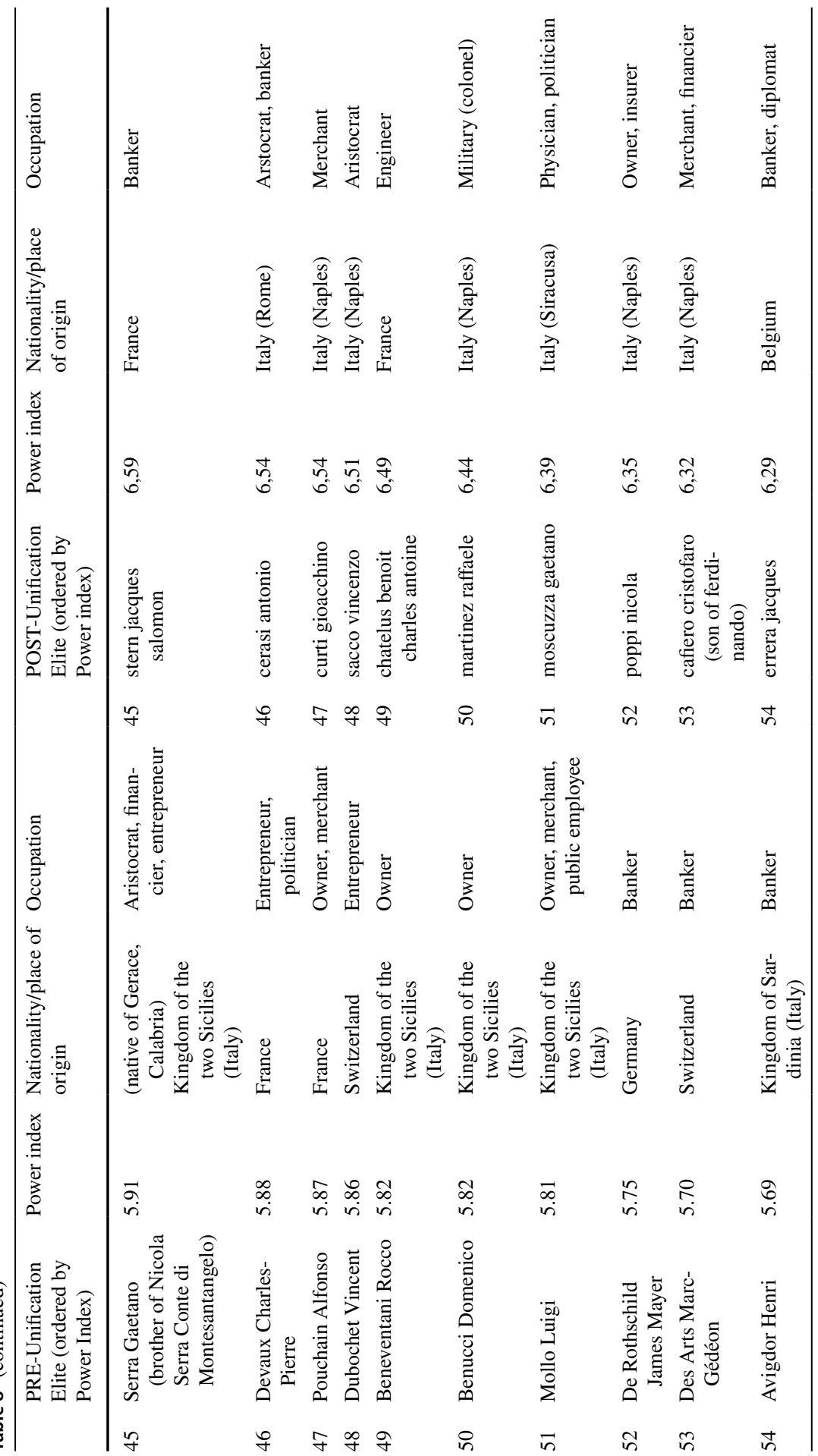




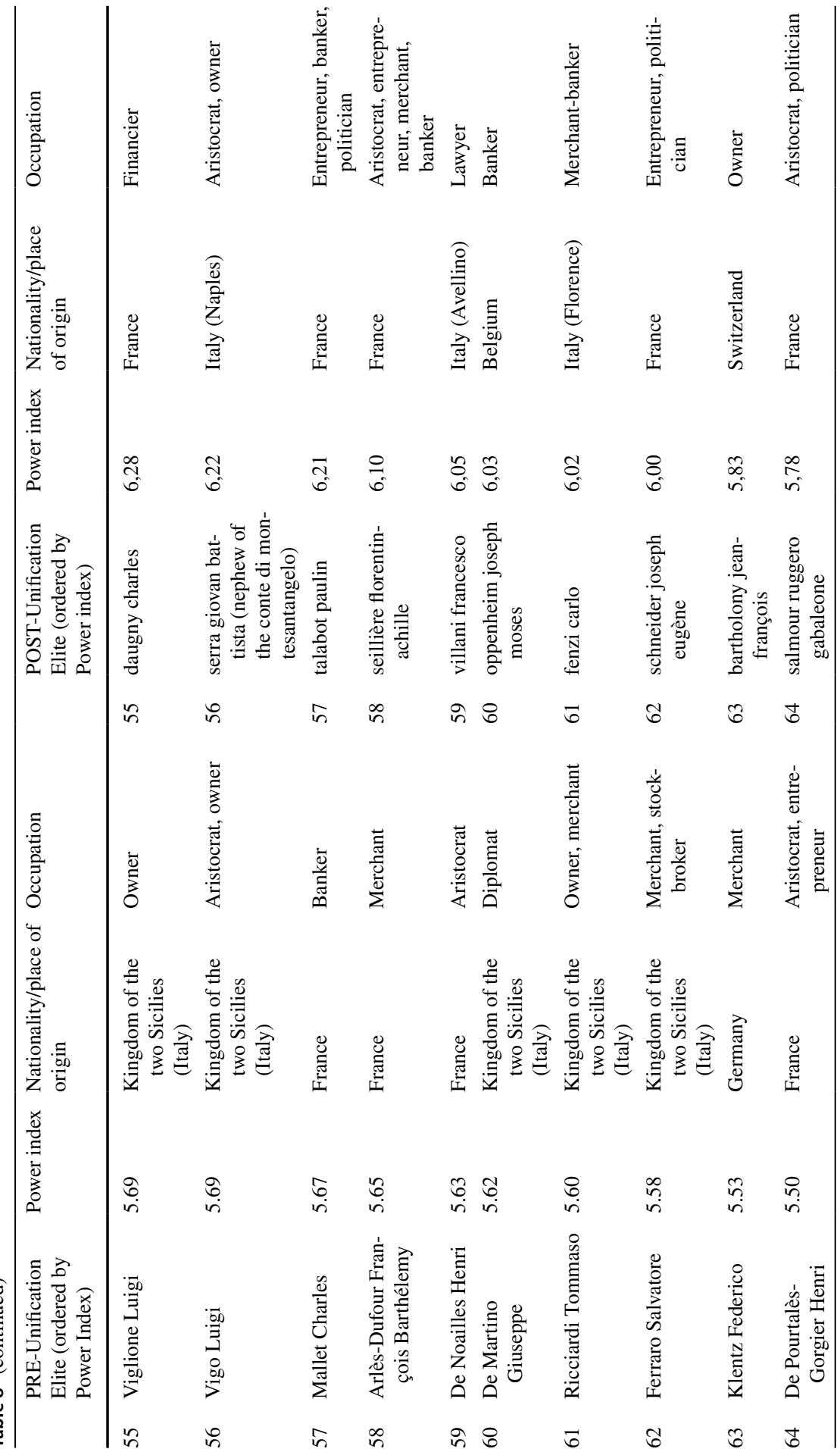




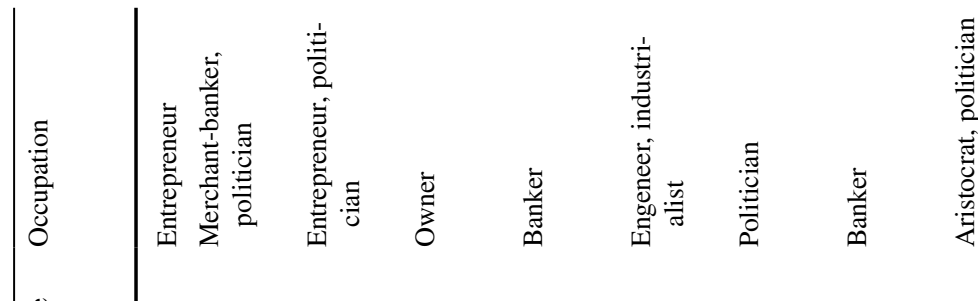

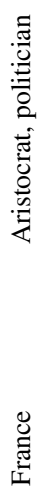

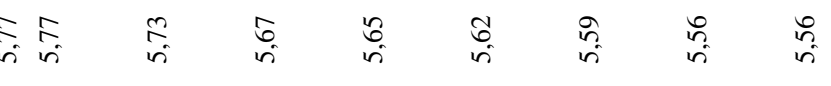

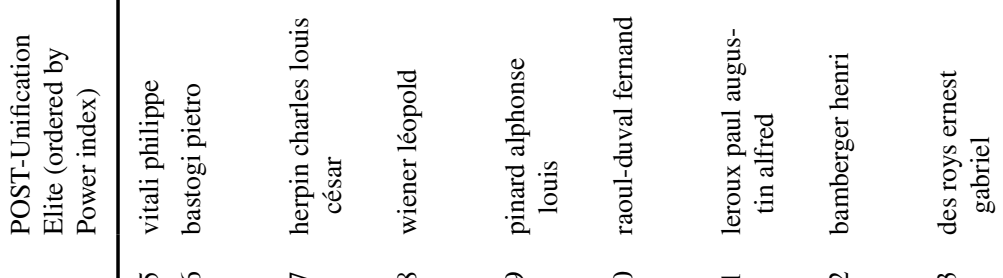

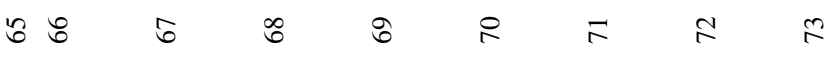

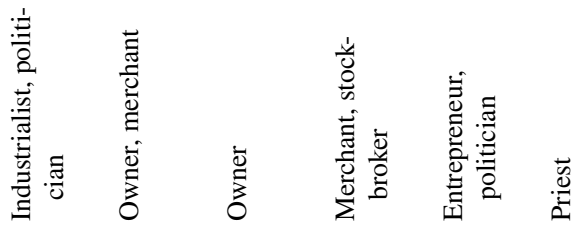

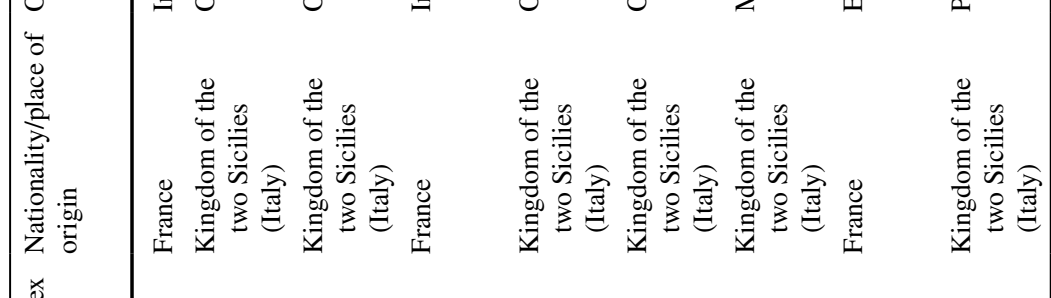

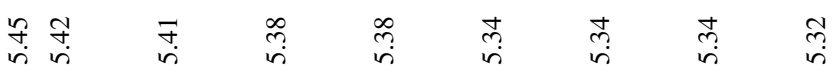

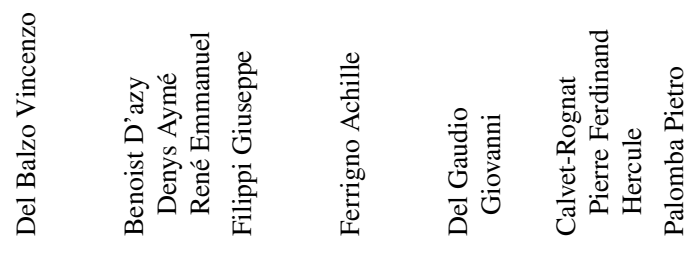

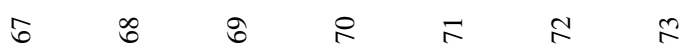




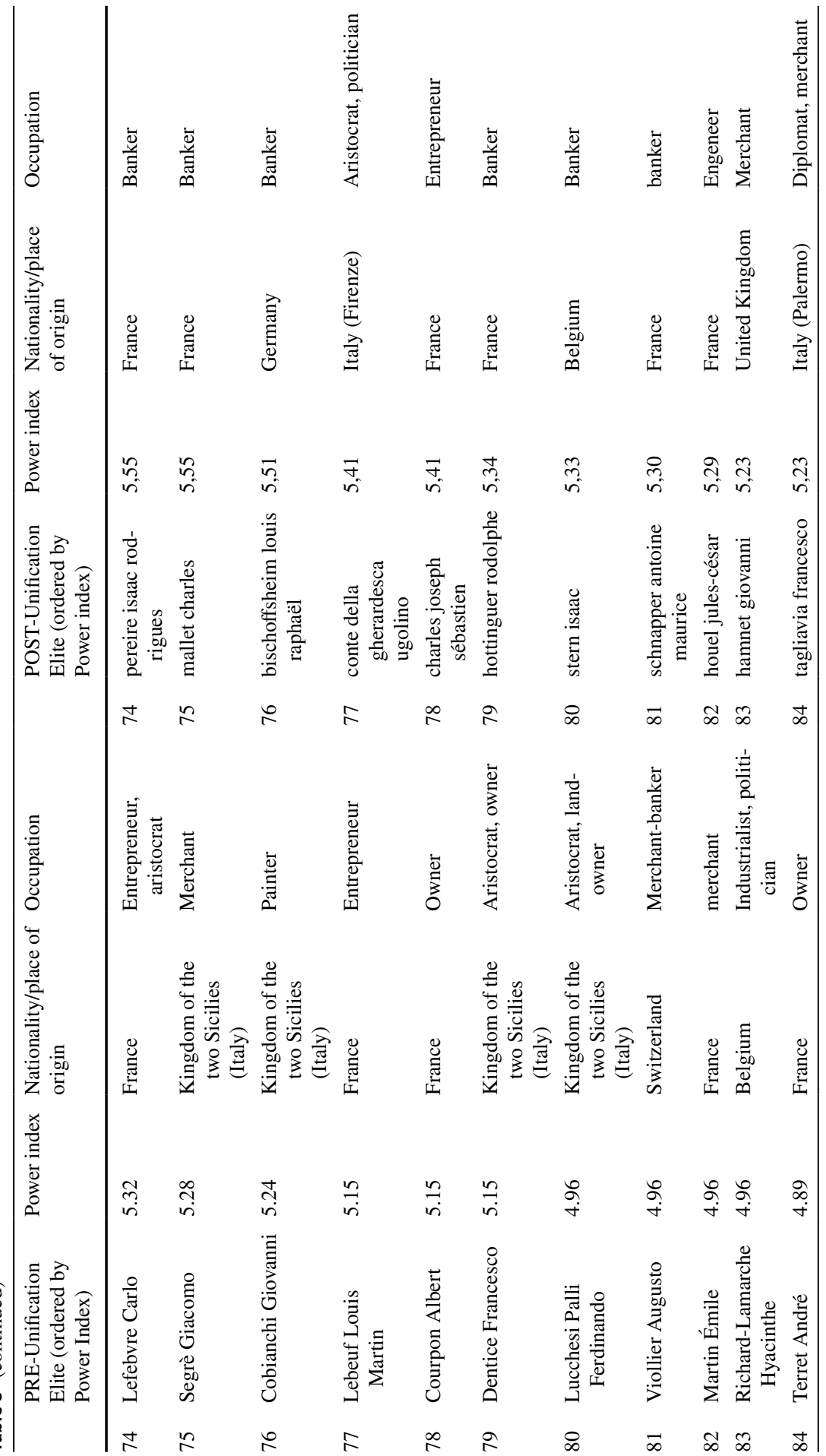




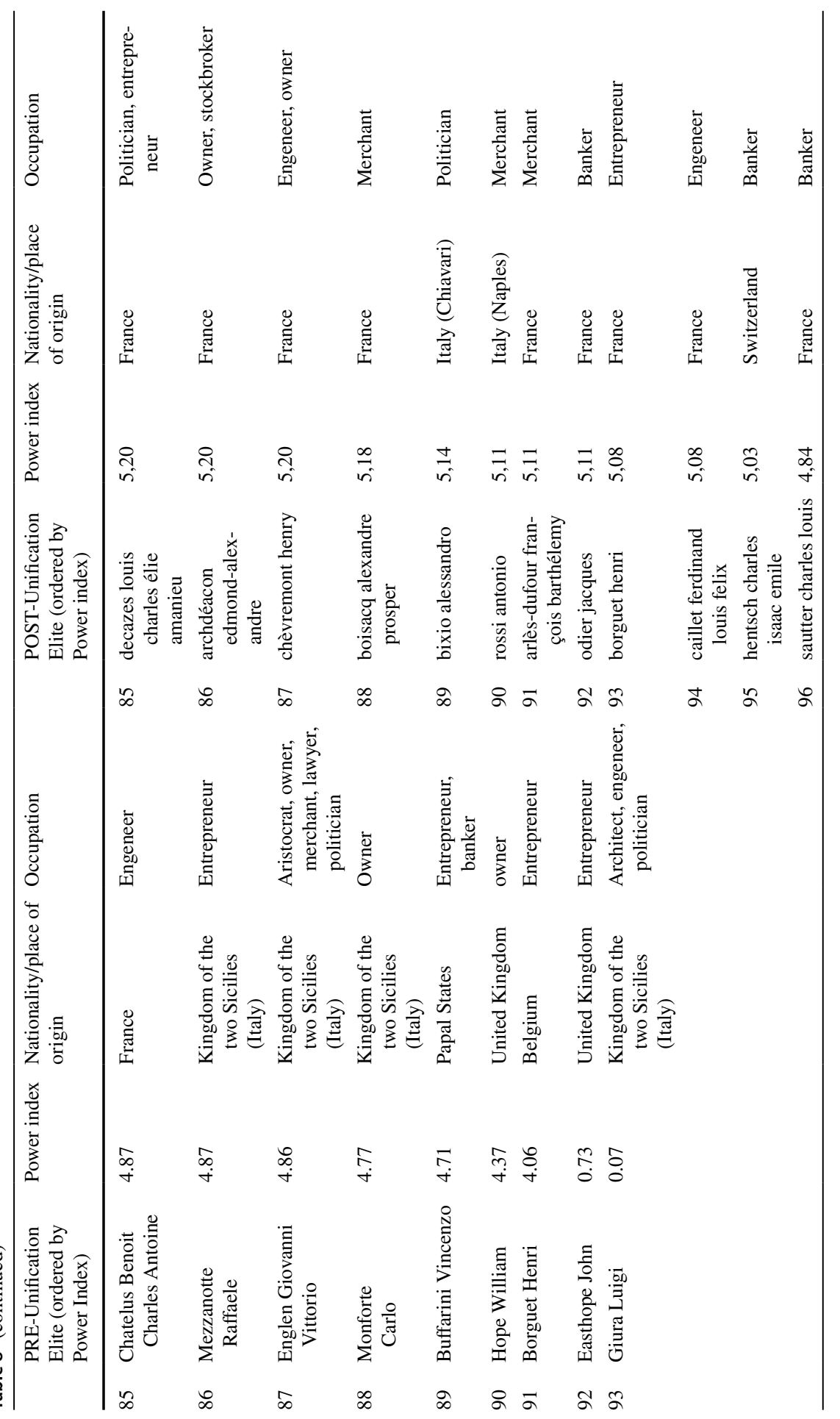




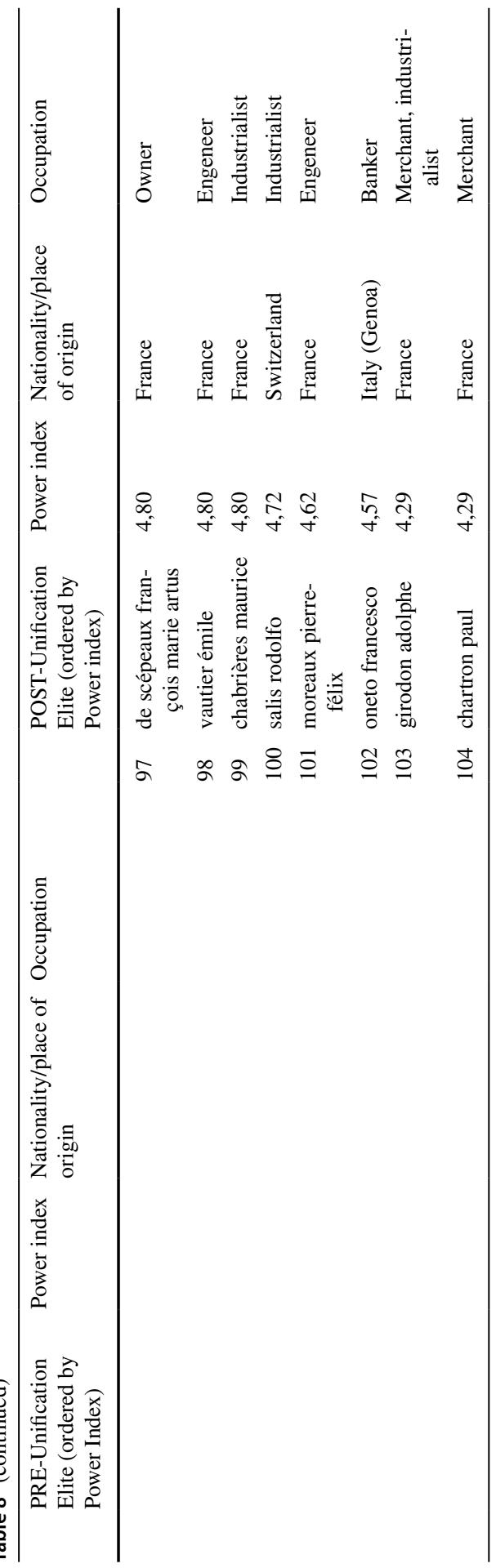


Table 9 OLS estimation of Eq. (2), without interactions elite and finance (disaggregated sectors)

\begin{tabular}{|c|c|c|c|c|}
\hline & $\begin{array}{l}\text { (1) } \\
\text { Power index }\end{array}$ & $\begin{array}{l}(2) \\
\text { Power index }\end{array}$ & $\begin{array}{l}(3) \\
\text { Power index }\end{array}$ & $\begin{array}{l}\text { (4) } \\
\text { Power index }\end{array}$ \\
\hline Time & $\begin{array}{l}1.164 * * * \\
(0.0938)\end{array}$ & $\begin{array}{l}1.401 * * * \\
(0.0921)\end{array}$ & $\begin{array}{l}0.217 \\
(0.214)\end{array}$ & $\begin{array}{l}0.428 * * \\
(0.216)\end{array}$ \\
\hline Elite & $\begin{array}{l}1.853 * * * \\
(0.116)\end{array}$ & $\begin{array}{l}1.648^{* * * *} \\
(0.123)\end{array}$ & $\begin{array}{l}1.885 * * * \\
(0.167)\end{array}$ & $\begin{array}{l}1.474 * * * \\
(0.189)\end{array}$ \\
\hline Elite $*$ time & $\begin{array}{l}0.336^{*} \\
(0.176)\end{array}$ & $\begin{array}{l}0.318 * \\
(0.182)\end{array}$ & $\begin{array}{l}-0.260 \\
(0.277)\end{array}$ & $\begin{array}{l}0.226 \\
(0.275)\end{array}$ \\
\hline Banking & & $\begin{array}{l}0.159 \\
(0.103)\end{array}$ & & $\begin{array}{l}0.392 * * \\
(0.182)\end{array}$ \\
\hline Banking * time & & $\begin{array}{l}0.850 * * * \\
(0.114)\end{array}$ & & $\begin{array}{l}0.922 * * * \\
(0.212)\end{array}$ \\
\hline Insurance & & $\begin{array}{l}2.393 * * * \\
(0.0845)\end{array}$ & & $\begin{array}{l}3.090 * * * \\
(0.160)\end{array}$ \\
\hline Insurance $*$ time & & $\begin{array}{l}-1.448^{* * *} \\
(0.103)\end{array}$ & & $\begin{array}{l}-0.494 * * \\
(0.217)\end{array}$ \\
\hline Finance (other) & & $\begin{array}{l}0.605 * * * \\
(0.132)\end{array}$ & & $\begin{array}{l}0.836 * * * \\
(0.236)\end{array}$ \\
\hline Finance (other) $*$ time & & $\begin{array}{l}-0.500^{* * *} \\
(0.161)\end{array}$ & & $\begin{array}{l}0.543 * \\
(0.281)\end{array}$ \\
\hline Foreign & $\begin{array}{l}-0.511^{* * *} \\
(0.0718)\end{array}$ & $\begin{array}{l}-0.111^{*} \\
(0.0633)\end{array}$ & $\begin{array}{l}-0.722 * * * \\
(0.132)\end{array}$ & $\begin{array}{l}-0.0679 \\
(0.113)\end{array}$ \\
\hline Foreign $*$ time & $\begin{array}{l}-0.235^{* * *} \\
(0.0898)\end{array}$ & $\begin{array}{l}-0.590 * * * \\
(0.0835)\end{array}$ & $\begin{array}{l}0.109 \\
(0.194)\end{array}$ & $\begin{array}{l}-0.0652 \\
(0.189)\end{array}$ \\
\hline International trade & & $\begin{array}{l}-0.759 * * * \\
(0.110)\end{array}$ & & $\begin{array}{l}-0.278 \\
(0.189)\end{array}$ \\
\hline International trade $*$ time & & $\begin{array}{l}-1.271 * * * \\
(0.137)\end{array}$ & & $\begin{array}{l}-0.288 \\
(0.334)\end{array}$ \\
\hline Trade (other) & & $\begin{array}{l}-0.733 * * * \\
(0.0883)\end{array}$ & & $\begin{array}{l}-0.431^{* *} \\
(0.168)\end{array}$ \\
\hline Trade (other) $*$ time & & $\begin{array}{l}-0.604 * * * \\
(0.104)\end{array}$ & & $\begin{array}{l}-0.326 \\
(0.219)\end{array}$ \\
\hline Manufacturing & $\begin{array}{l}-0.285^{* * *} \\
(0.0985)\end{array}$ & $\begin{array}{l}-0.263 * * * \\
(0.0939)\end{array}$ & $\begin{array}{l}0.447 * * \\
(0.214)\end{array}$ & $\begin{array}{l}0.191 \\
(0.177)\end{array}$ \\
\hline Manufacturing * time & $\begin{array}{l}-0.123 \\
(0.106)\end{array}$ & $\begin{array}{l}-0.228 * * \\
(0.105)\end{array}$ & $\begin{array}{l}0.618^{* * * *} \\
(0.204)\end{array}$ & $\begin{array}{l}0.415 * * \\
(0.204)\end{array}$ \\
\hline Publ. util. \&transp. & $\begin{array}{l}1.264 * * * \\
(0.108)\end{array}$ & $\begin{array}{l}1.332 * * * \\
(0.104)\end{array}$ & $\begin{array}{l}1.907 * * * \\
(0.214)\end{array}$ & $\begin{array}{l}1.678^{* * * *} \\
(0.202)\end{array}$ \\
\hline Publ. util. \& transp. * time & $\begin{array}{l}-0.821^{* * * *} \\
(0.124)\end{array}$ & $\begin{array}{l}-1.022 * * * \\
(0.122)\end{array}$ & $\begin{array}{l}-0.287 \\
(0.247)\end{array}$ & $\begin{array}{l}-0.490^{*} \\
(0.251)\end{array}$ \\
\hline Politician (POST-unification) & $\begin{array}{l}0.0563 \\
(0.187)\end{array}$ & $\begin{array}{l}0.0785 \\
(0.158)\end{array}$ & $\begin{array}{l}0.120 \\
(0.263)\end{array}$ & $\begin{array}{l}0.149 \\
(0.214)\end{array}$ \\
\hline Politician (POST-unification) $*$ time & $\begin{array}{l}0.478 * * \\
(0.218)\end{array}$ & $\begin{array}{l}0.366^{*} \\
(0.193)\end{array}$ & $\begin{array}{l}0.526 \\
(0.368)\end{array}$ & $\begin{array}{l}0.166 \\
(0.322)\end{array}$ \\
\hline
\end{tabular}


Table 9 (continued)

\begin{tabular}{lllll}
\hline & $(1)$ & $(2)$ & $(3)$ & $(4)$ \\
& Power index & Power index & Power index & Power index \\
\hline Differentiated & $0.462 * * *$ & $0.785 * * *$ & $-0.743 * * *$ & 0.194 \\
& $(0.0965)$ & $(0.0893)$ & $(0.214)$ & $(0.174)$ \\
Finance & $1.945 * * *$ & & $2.785 * * *$ & \\
Finance * time & $(0.0914)$ & & $(0.187)$ & \\
& $-0.952 * * *$ & & -0.200 & \\
Trade & $(0.101)$ & & $(0.207)$ & \\
& $-0.878 * * *$ & & $(0.199)$ & \\
Trade $*$ time & $(0.0969)$ & & -0.0871 & \\
Constant & $-0.482 * * *$ & & $(0.246)$ & $1.761 * * *$ \\
Observations & $(0.110)$ & & $1.891 * * *$ & $(0.158)$ \\
R-squared & $2.241 * * *$ & $2.057 * * *$ & $(0.182)$ & 1240 \\
\hline
\end{tabular}

Robust standard errors in parentheses $* * * p<0.01$; ** $p<0.05 ; * p<0.1$. Regressions 1 and 3 are run on the full sample, regressions 2 and 4 on the subsample of 620 actors present before and after Unification

Table 10 OLS estimation of Eq. (2), with interactions elite with finance (disaggregated sectors)

\begin{tabular}{|c|c|c|}
\hline & $\begin{array}{l}\text { (1) } \\
\text { Power index }\end{array}$ & $\begin{array}{l}(2) \\
\text { Power index }\end{array}$ \\
\hline Time & $\begin{array}{l}1.401 * * * \\
(0.0921)\end{array}$ & $\begin{array}{l}1.463 * * * \\
(0.0896)\end{array}$ \\
\hline Elite & $\begin{array}{l}1.648 * * * \\
(0.123)\end{array}$ & $\begin{array}{l}2.549 * * * \\
(0.179)\end{array}$ \\
\hline Elite $*$ time & $\begin{array}{l}0.318^{*} \\
(0.182)\end{array}$ & $\begin{array}{l}-0.141 \\
(0.360)\end{array}$ \\
\hline Banking & $\begin{array}{l}0.159 \\
(0.103)\end{array}$ & $\begin{array}{l}0.272 * * \\
(0.109)\end{array}$ \\
\hline Banking $*$ time & $\begin{array}{l}0.850 * * * \\
(0.114)\end{array}$ & $\begin{array}{l}0.768 * * * \\
(0.120)\end{array}$ \\
\hline Insurance & $\begin{array}{l}2.393 * * * \\
(0.0845)\end{array}$ & $\begin{array}{l}2.485 * * * \\
(0.0828)\end{array}$ \\
\hline Insurance $*$ time & $\begin{array}{l}-1.448 * * * \\
(0.103)\end{array}$ & $\begin{array}{l}-1.545^{* * * *} \\
(0.102)\end{array}$ \\
\hline Finance (other) & $\begin{array}{l}0.605 * * * \\
(0.132)\end{array}$ & $\begin{array}{l}0.627 * * * \\
(0.131)\end{array}$ \\
\hline Finance (other) $*$ time & $\begin{array}{l}-0.500 * * * \\
(0.161)\end{array}$ & $\begin{array}{l}-0.543 * * * \\
(0.161)\end{array}$ \\
\hline Foreign & $\begin{array}{l}-0.111 * \\
(0.0633)\end{array}$ & $\begin{array}{l}-0.117 * \\
(0.0630)\end{array}$ \\
\hline Foreign $*$ time & $\begin{array}{l}-0.590 * * * \\
(0.0835)\end{array}$ & $\begin{array}{l}-0.581 * * * \\
(0.0833)\end{array}$ \\
\hline
\end{tabular}


Table 10 (continued)

(1)

(2)

Power index Power index

International trade $-0.759 * * * \quad-0.708 * * *$

International trade * time

(0.110)

(0.109)

$-1.271 * * *$

$-1.316^{* * * *}$

(0.137)

(0.136)

Trade (other)

$-0.733 * * *$

$-0.688^{* * *}$

(0.0883)

(0.0857)

Trade (other) * time

$-0.604 * * *$

$-0.641 * * *$

(0.104)

(0.102)

Manufacturing

$-0.263 * * *$

$-0.213 * *$

(0.0939)

(0.0927)

Manufacturing * time

$-0.228 * *$

$-0.271 * * *$

(0.105)

(0.104)

Public utilities

$1.332 * * *$

$1.364 * * *$

(0.104)

(0.0993)

Public utilities * time

$-1.022 * * *$

$-1.034 * * *$

(0.122)

(0.118)

Politician (POST-unification)

0.0785

0.104

(0.158)

(0.155)

Politician (POST-unification) * time

$0.366^{*}$

$0.354 *$

(0.193)

(0.190)

Differentiated

$0.785^{* * *}$

$0.780 * * *$

(0.0893)

(0.0895)

Bank * elite

Bank * elite * time

$-0.892 * * *$

(0.226)

0.105

(0.403)

Insurance $*$ elite

$-1.037 * * *$

(0.213)

$1.353 * * *$

(0.430)

0.692 ***

Finance (other) * elite

(0.216)

$-0.394$

(0.594)

Finance (other) $*$ elite $*$ time

$1.986 * * *$

Constant

$2.057 * * *$

(0.0775)

Observations

(0.0806)

6196

R-squared

0.468

0.471

Robust standard errors in parentheses *** $p<0.01$; ** $p<0.05$; * $p<0.1$. Regressions are run on the full sample 


\section{References}

A'Hearn B (2000) Could Southern Italians cooperate? «Banche Popolari» in the «Mezzogiorno». J Econ Hist 60(1):67-93

A'Hearn B (2005) Finance-led divergence in the regions of Italy. Financ Hist Rev 12(1):7-41

A'Hearn B, Venables AJ (2013) Regional disparities: internal geography and external trade. In: Toniolo $\mathrm{G}$ (ed) The Oxford handbook of the Italian economy since unification. Oxford University Press, Oxford, pp 599-630

Acemoglu D, Robinson JA (2008) Persistence of power, elites, and institutions. Am Econ Rev 98(1):267-293

Acemoglu D, Robinson JA (2012) Why nations fail: the origins of power, prosperity, and poverty. Crown Books

Aliberti G (1974) Ambiente e società nell'Ottocento meridionale, Roma

Aliberti G (1979) Strutture sociali e classe dirigente nel Mezzogiorno liberale, Roma

Banfield EC (1958) Moral basis of a backward society. The Free Press, Glencoe

Basile R, Ciccarelli C (2018) The location of the Italian manufacturing industry, 1871-1911: a sectoral analysis. J Econ Geogr 18(3):627-661. https://doi.org/10.1093/jeg/lbx033

Batagelj V (2009) Social network analysis, large-scale. Encyclopedia of complexity and systems science. Springer, New York, pp 8245-8265

Batagelj V, Doreian P, Ferligoj A, Kejzar N (2014) Understanding large temporal networks and spatial networks: exploration, pattern searching, visualization and network evolution, vol 2. Wiley, London

Best H, Higley J (eds) (2017) The Palgrave handbook of political elites. Springer, Berlin

Cafagna L (1988) Modernizzazione attiva e modernizzazione passiva. Meridiana 2(2):229-240

Cafagna L (1989) Dualismo e sviluppo nella storia d'Italia, Padova

Caglioti DL (2003) Élites in movimento: l'emigrazione svizzero-tedesca a Napoli nell'Ottocento. In: Arru A, Ramella F (eds) L'Italia delle migrazioni interne, Roma, pp 207-226

Caglioti DL (2008) Trust, business group, and social capital: building a protestant entrepreneurial network in 19th century Naples'. Journal of Modern Italian Studies 13(2):219-236

Cameron RE (1961) France and the economic development of Europe, 1800-1914. Princeton University Press, Princeton

Carroll WK, Fennema M (2002) Is there a transnational business community? International Sociology 173:393-419

Cassis Y (1997) Big business: the European experience in the Twentieth century. Oxford University Press, New York

Cassis Y (2010) Capitals of capital: the rise and fall of international financial centres 1780-2009. Oxford University Press, New York

Cassis Y, Telesca G (2018) Financial elites and European banking: historical perspectives. Oxford University Press, Oxford

Ciccarelli C, Fachin S (2017) Regional growth with spatial dependence: a case study on early Italian industrialization. Pap Reg Sci 96(4):675-695. https://doi.org/10.1111/pirs.12217

Ciccarelli C, Fenoaltea S (2013) Through the magnifying glass: provincial aspects of industrial growth in post-Unification Italy. Econ Hist Rev 66:57-85. https://doi.org/10.1111/j.1468-0289.2011.00643.x

Ciccarelli C, Weisdorf J (2019) Pioneering into the past: regional literacy developments in Italy before Italy. Eur Rev Econ Hist 23(3):329-364. https://doi.org/10.1093/ereh/hey014

Collezione delle leggi e de' decreti reali del Regno delle Due Sicilie (Laws and Decrees of the Kingdom of the Two Sicilies) (1860) per l'anno 1860, Napoli

Collezione delle leggi e decreti emanati nelle Provincie Continentali dell'Italia meridionale (Laws and Decrees for the Southern Italy Provinces) (1860) per l'anno 1860, Napoli

Colpan AM, Hikino T, Lincoln JR (2010) The Oxford handbook of business groups. Oxford University Press, New York

Conti G, Schisani MC (2011) I banchieri italiani e la haute banque nel Risorgimento e dopo l'Unità. Società e Storia 34(131):133-170

Cuciniello O (1976) La Banca Fruttuaria del Regno delle Due Sicilie, 1827-1874. Revue internationale d'histoire de la Banque 13:73-116

Daniele V, Malanima P (2011) Il divario Nord-Sud in Italia 1861-2011, Soveria Mannelli

Daniele V, Malanima P, Ostuni N (2018) Geography, market potential and industrialization in Italy 18712001. Pap Reg Sci 97(Issue3):639-662. https://doi.org/10.1111/pirs.12275 
Davis JA (1979) Società e imprenditori nel Regno Borbonico. 1815-1860, Laterza, Roma-Bari

De Benedetti A (1990) Il sistema industriale 1880-1940, in Storia d'Italia. Le regioni dall'Unità ad oggi. In: Macry P, Villani P (eds) La Campania, Torino, Einaudi, pp 445-605

De Matteo L (2008) Banche, credito ed economia nel Mezzogiorno continentale tra Restaurazione e crisi postunitaria. In: Bermond C, Cova A, Moioli A (eds) "La Banca". Annale 23, Torino

De Matteo L (2013) Una "economia alle strette" nel Mediterraneo. Modelli di sviluppo, imprese e imprenditori a Napoli e nel Mezzogiorno nell'Ottocento, Napoli

Demarco D (1960) Il crollo del Regno delle due Sicilie. La struttura sociale, Napoli

Di Martino P, Felice E, Vasta M (2019) A tale of two Italies: 'access-orders' and the Italian regional divide. Scand Econ Hist Rev. https://doi.org/10.1080/03585522.2019.1631882

Dorso G (1925) La rivoluzione meridionale, saggio storico-politico sulla lotta politica in Italia, Torino

Dumoulin M (1990) Les relations économique italo-belges (1861-1914), Bruxelles

Everett MG, Borgatti SP (2013) The dual-projection approach for two-mode networks. Soc Netw 35(2):204-210

Federico G, Tena-Junguito A (2014) The ripples of the industrial revolution: exports, economic growth, and regional integration in Italy in the early nineteenth century. Eur Rev Econ Hist 18(3):349-369. https://doi.org/10.1093/ereh/heu007

Federico G, Nuvolari A, Vasta M (2019) The origins of the Italian regional divide: evidence from Real Wages, 1861-1913. J Econ Hist 79(1):63-98. https://doi.org/10.1017/S0022050718000712

Felice E (2012) Regional convergence in Italy (1891-2001): testing human and social capital. Cliometrica 6(3):267-306

Felice E (2013) Perché il Sud è rimasto indietro, Bologna

Felice E (2018) The socio-institutional divide: explaining Italy's long-term regional differences. J Interdiscip Hist XLIX(1):43-70

Felice E, Vasta M (2015) Passive modernization? The new human development index and its components in Italy's regions (1871-2007). Eur Rev Econ Hist 19(1):44-66. https://doi.org/10.1093/ereh/heu01 8

Felice E, Vecchi G (2015) Italy's growth and decline, 1861-2011. J Interdiscip Hist 45(4):507-548. https ://doi.org/10.1162/JINH_a_00757

Fellman S (2014) Prosopographic studies business leaders for understanding industrial and corporate change. Business History 56(1):5-21

Fortunato G (1911) Il Mezzogiorno e lo Stato italiano, 2 voll., Bari

Franchetti L, Sonnino S (1877) La Sicilia nel 1876. Condizioni politiche e amministrative, Firenze

Frascani P (1990) Mercato e commercio a Napoli dopo 1'Unità. In: Macry P, Villani P (eds) La Campania, Storia d'Italia, Le regioni IX. Einaudi, Torino

Galasso G (2009) La disarticolazione di Napoli dal Mezzogiorno. In "Ventunesimo Secolo", vol 8, 20, Napoli, pp 11-24

Genovesi A (1775) Lettere familiari, vol. II, Venezia

Gille B (1965-67) Histoire de la maison Rothschild, 2 voll., Droz, Genève

Gille B (1968) Les investissements français en Italie (1815-1914), Torino

Gramsci A (1935) Alcuni temi della questione meridionale, Francia

Hausman WJ, Hertner P, Wilkins M (2008) Global electrification: multinational enterprise and international finance in the history of light and power, 1878-2007. Cambridge University Press, New York

$\mathrm{Hu} \mathrm{HB}$, Wang XF (2008) Unified index to quantifying heterogeneity of complex networks. Phys A 387(14):3769-3780

Iuzzolino G, Pellegrini G, Viesti G (2013) Regional convergence. In: Toniolo G (ed) The Oxford handbook of the Italian Economy since unification. Oxford University Press, Oxford, pp 571-598

Lemercier C, Picard E (2012) Quelle approche prosopographique? In: Rollet L, Nabonnaud P (eds) Les uns et les autres. Biographies et prosopographies en histoire des sciences, Nancy, pp 605-630

Macry P (1974) Mercato e Società nel Regno di Napoli, Napoli

Macry P, Villani P (eds) (1990) La Campania, Storia d'Italia, Le regioni IX, Einaudi

Massafra A (ed) (1988) Il Mezzogiorno preunitario: economia, società e istituzioni, Dedalo

Ministero di Industria e Commercio (1863) Direzione di Statistica, Censimento generale della popolazione del Regno d'Italia (al 31 dicembre 1861), Torino

Missiaia A (2016) Where do we go from here? Market access and regional development in Italy (18711911). Eur Rev Econ Hist 20(2):215-241

Missiaia A (2019) Market versus endowment: explaining early industrial location in Italy (1871-1911). Cliometrica 13:127. https://doi.org/10.1007/s11698-018-0172-6 
Newman MEJ (2003) Mixing patterns in networks. Phys Rev E 67:026126

Nitti FS (1900) Nord e Sud: prime linee di un'inchiesta sulla ripartizione territoriale delle entrate e delle spese dello Stato in Italia, Torino

North DC (1990) Institutions, institutional change and economic performance. Cambridge University Press

Nuvolari A, Vasta M (2017) The geography of innovation in Italy, 1861-1913: evidence from patent data. Eur Rev Econ Hist XXI(1):326-356

Palmieri G (1788) Riflessioni sulla pubblica felicità relativamente al regno di Napoli, Napoli

Pescosolido G (2017) La questione meridionale in breve Centocinquant'anni di storia. Donzelli, Roma

Putnam R (1993) Making democracy work: civic traditions in modern Italy. Princeton University Press, Princeton

Rajan RG, Zingales L (2003) The great reversals: the politics of financial development in the twentieth century. J Financ Econ 69:5-50

Schisani MC (2001) La Borsa di Napoli. Istituzione, regolazione e attività, Napoli

Schisani MC (2010) How to Make a Potentially Defaulting Country Credible: Karl Rothschild, the Neapolitan Debt and Financial Diplomacy (1821-26). Rivista di Storia Economica, a. XXVI 2:233-277

Schisani MC (2015) C.M. Rothschild e figli" di Napoli. In: Lacerenza G (ed) Per i 150 anni della Comunità Ebraica di Napoli. Saggi e Ricerche, Archivio di Studi Ebraici, VII. Centro di Studi Ebraici, Napoli, pp 9-32

Schisani MC (2019) Dinamiche professionali e reti di re/azioni di un 'uomo d'affari' di successo a Napoli nel periodo del/a prima globalizzazione. Domenico Gallotti (1831-1905), Storia Economica, 2018/2, pp. 379-414

Schisani MC, Caiazzo F (2016) Networks of power and networks of capital: evidence from a peripheral area of the first globalisation. The energy sector in Naples: from gas to electricity (1862-1919). Bus Hist 58:2

Scott J (1997) Corporate business and capitalist class. Oxford University Press, New York

Tarr J, Dupuy G (eds) (1988) Technology and the rise of the networked City in Europe and America, Philadelphia. Temple University Press, Philadelphia

Toninelli P, Pavese C (2012) Joint-stock companies dynamics, legal institutions and regional economic disparities in Italy (1858-1914). In: Paper presented at the 16th annual conference of the european business history association and 1st joint conference with business history society of Japan, 30 August-1 September 2012 (Session 9.D: Regional Differentiation in an International Perspective)

Van Den Brink R, Borm P, Hendrickx R, Owen G (2008) Characterizations of the $\beta$ - and the degree network power measure. Theor Decis 64:519-536

Vecchi G (ed) (2017) Measuring wellbeing. A history of Italian living standards. Oxford University Press, Oxford

Villari P (1878) Le lettere meridionali ed altri scritti sulla questione sociale in Italia, Firenze

Wasserman S, Faust K (1994) Social network analysis: methods and applications. Cambridge University Press, Cambridge

Wilkins M, Schröter HG (1998) The free-standing company in the world economy, 1830-1996. Oxford University Press, Oxford

Publisher's Note Springer Nature remains neutral with regard to jurisdictional claims in published maps and institutional affiliations. 